\title{
Scoring The President: Myth and Politics in John Williams's JFK and Nixon
}

\author{
FRANK LEHMAN
}

\begin{abstract}
Throughout his career, John Williams has set the musical tone for the American presidency, most elaborately with his scores for Oliver Stone's controversial films JFK (1991) and Nixon (1995). While invested in capturing the character of these commanders in chief through musical codes, Williams's soundtracks are equally engaged in the act of the evocation and telling of "history." Specifically, they construct a tragic myth of 1960s America in which the promise represented by JFK is destroyed from without, and Nixon from within, both by the malevolent forces of the military-industrial complex. In considering the thematic and dramatic means by which Williams paints his orchestral portraits, I reveal the extent to which music supports Stone's paranoiac narratives, especially in cases where the director's collage-like visual aesthetic puts pressure on the otherwise nostalgic traits of Williams's default tonal style.

I offer a music-analytical approach to JFK and Nixon informed by interviews, studies of political mythology and paranoia, and musicological appraisals of Williams's music. Stone's 1960s-as-lapsarian-metanarrative positions Kennedy as a romanticized absence, an image of the fabular fallen King, and Williams renders him as a public recollection rather than a human being with interiority. Nixon, by contrast, is a tragic antihero, consumed by dark forces of history and an abundance of ambivalent thematic material. Particular attention is paid to the dismantling of Kennedy's noble leitmotif during JFK's prologue and motorcade sequence and to the near-fascistic musical accompaniment of Nixon's speeches. Having demonstrated the active role these scores play, I conclude that Williams's music constitutes an authoring of history in a strong, albeit postmodern, sense, consistent with but independent from Stone's screenplay.
\end{abstract}

\section{JFK and Nixon}

At the conclusion of Oliver Stone's Nixon (1995), the title character (Anthony Hopkins) stands alone in a White House hallway. ${ }^{1}$ His resignation imminent, Richard Nixon turns to Aaron Shikler's posthumous portrait of John Fitzgerald Kennedy and confronts the specter of his predecessor. The image of JFK that stares down on him is not the inspirational hero who penned Profiles in Courage, but a haunted and remote figure, arms folded and face downcast. ${ }^{2}$ As Nixon's gaze meets this ghostly representation, the music swells on a dissonant pentachord-a gradually stacked column $(\mathrm{A} b-\mathrm{B} b-\mathrm{C} b-\mathrm{C}-\mathrm{D})$ buttressed on either end by a high $\mathrm{D}$ and a low $\mathrm{C}$ pedal (Example 1). That $\mathrm{C}$ forms the stable base for the rest of the sequence. It is an effective root for the cluster-chord, sonically grounding what will become the film's most significant moment of anagnorisis - the kind of revelation

${ }^{1}$ DVD time 3:19:32. All timings come from director's-cut versions of discussed films. See Oliver Stone, dir. Nixon, DVD (1995, Burbank, CA: Buena Vista Home Entertainment, 2008); and Oliver Stone, dir. JFK, DVD. (1991, Burbank, CA: Warner Bros. Home Video, 2011).

${ }^{2}$ An analogous shot occurs in Robert Reiner's film The American President, also from 1995 (1:37:55). There too, JFK's visage appears during the presidential protagonist's darkest hour, albeit with much brighter music from Marc Shaiman. For analysis, see John Nein, "The Republic of Sorkin," in Considering Aaron Sorkin: Essays on the Politics, Poetics, and Sleight of Hand in the Films and Television Series, ed. Thomas Fahey (Jefferson, NC: McFarland, 2005), 202. 


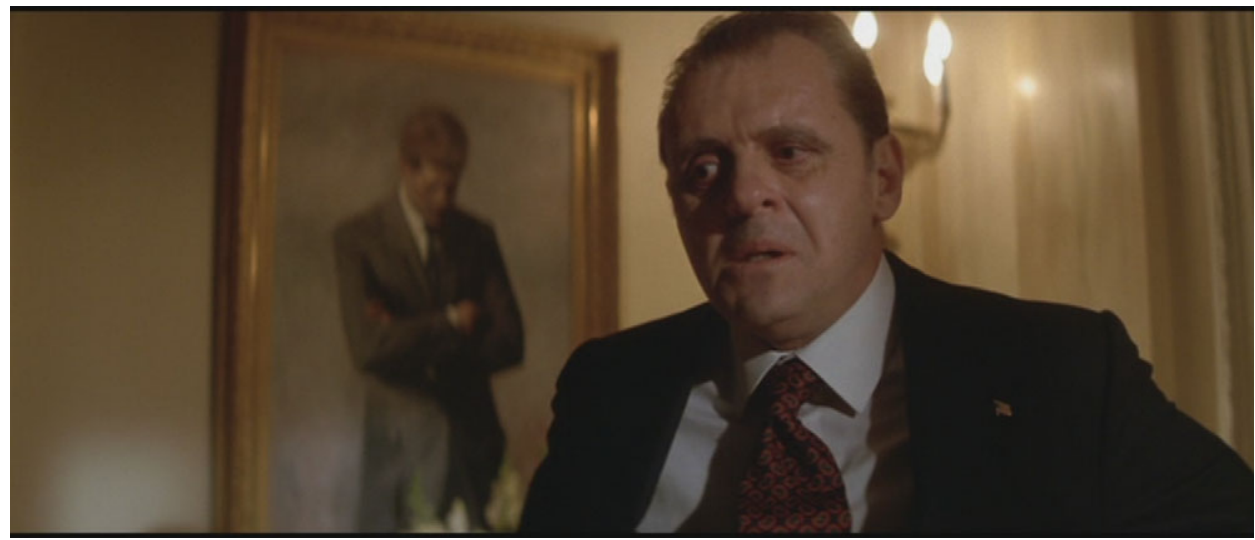

Figure 1. Anthony Hopkins as US President Richard Nixon confronting JFK in Nixon (1995, Cinergi Pictures Entertainment, Inc.), directed by Oliver Stone and produced by Dan Halsted, Eric Hamburg, Richard Rutowski, Oliver Stone, Clayton Townsend, and Andrew G. Vajna.

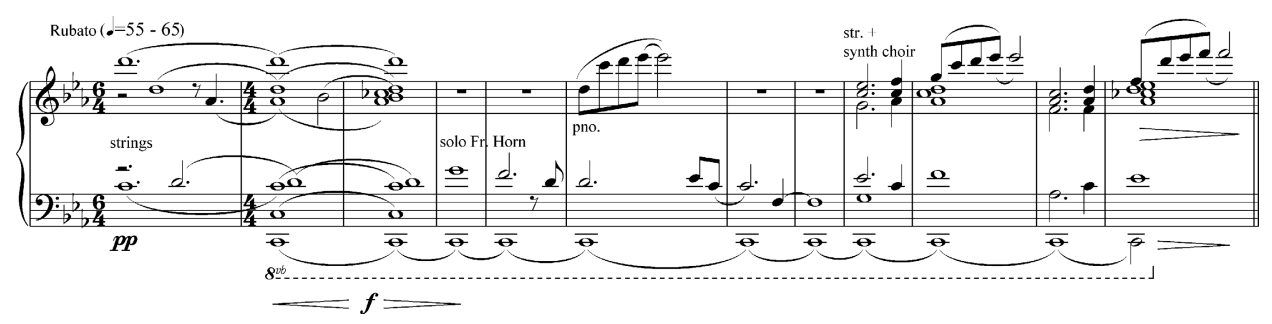

Example 1. Music for Nixon's confrontation with JFK from Nixon (1995, Cinergi Pictures Entertainment, Inc.), directed by Oliver Stone and produced by Dan Halsted, Eric Hamburg, Richard Rutowski, Oliver Stone, Clayton Townsend, and Andrew G. Vajna. Musical score by John Williams. Transcription by author.

that fundamentally changes a character's (and audience's) understanding of their dramatic situation. The sonority quickly subsides, leaving open a hollow and vacant soundscape. French horn and piano trade melodic fragments from some neverrealized theme, while synthesized choir traces a solemn diatonic progression, the vestige of a lost minor chorale. The tone is brooding and eerie, with music lending an almost religioso aura to the late-film revelation. ${ }^{3}$

It is over this aural canvas that Nixon utters the film's most incisive line of dialogue: "When they look at you, they see what they want to be," he concedes. "When they look at me, they see who they are." ${ }^{4}$ With his political career hours from ending, it is a figurative deathbed realization. ${ }^{5}$ Nixon expresses something that has hovered as subtext over the whole of his movie: Kennedy is a cipher, an

${ }^{3}$ All musical examples stem from the author's own transcriptions.

${ }^{4}$ See original screenplay in Eric Hamburg, ed., Nixon: An Oliver Stone Film (New York: Hyperion, 1995).

${ }^{5}$ Nixon's final words before the end credits roll are "I'm afraid.... There's darkness out there. I could always see where I was going. But it's dark out there. God, I've always been afraid of the dark." The mythic tone influences dialogue immediately preceding the scene as well, in which Nixon explains to Henry Kissinger and Alexander Haig that his resignation will be a bloody appeasement to the gods of war: "I am that sacrifice. ... All leaders must finally be sacrificed." 
imaginative projection, while he himself is the concrete, unflattering embodiment of the actual American character. ${ }^{6}$

This scene plays out an encounter between an inaccessible thirty-fifth president and a physically and psychologically far too close thirty-seventh. It is one of several thematic hinges between Stone's two controversial commander-in-chief films from the 1990s: JFK (1991) and Nixon (1995), both scored by film composer John Williams. The understatedly ominous cue deepens the connections latent between the two movies and is one instance among many where the soundtrack enlists musical topics and associations — tragedy, Americana, religion, obsession- to evoke and construct a mythicized version of U.S. history.

Both JFK and Nixon are aggressively stylized and, for mainstream cinema in the 1990s, unconventional exercises in political filmmaking. The former is not a biographical film as its title suggests, but a three-hour erection of what Oliver Stone called a "counter-myth" to the Warren commission's findings on the Kennedy assassination. JFK may well be the summit of what might be called the paranoid style in American cinema. ${ }^{7}$ David Cook, echoing many critics, positions it within a "paranoid conspiracy" genre, which first blossomed in the 1960s and '70s with assassination-centered films like Executive Action (1973) and The Parallax View (1974). ${ }^{8}$ JFK outdoes its models, jerking rapidly between historical footage, re-enactments, newsreels, models, still photographs, and courtroom scenes. This striking editorial vocabulary was well appreciated for its novelty and persuasive (if not necessarily sound) argumentative power. ${ }^{9}$ The film courted a firestorm of critique and condemnation, though only rarely was music mentioned in critical reactions. ${ }^{10}$ JFK's arsenal of special effects, sonic and otherwise, are hung on a single narrative frame, the prosecution of alleged (and ultimately acquitted) conspirator Claw Shaw (Tommy Lee Jones) by New Orleans District Attorney Jim Garrison (Kevin Costner). The result is an eclectic, seductive, and frequently tendentious

${ }^{6}$ This line from Stone's screenplay (co-written with Steven Revele and Christopher Wilkinson) distills the thesis of Tom Wicker's biography, One of Us (New York: Random House, 1991). Wicker argues that Nixon's ability to connect with voters stemmed from his own middle-class resentments, ambitions, and struggles. On this point, see also Michel Cieutat and Michel Ciment, "Interview with Oliver Stone,” in Oliver Stone: Interviews (Jackson: University Press of Mississippi, 2001), 172-82.

7 The phrase "paranoid style" owes to an influential article by Richard Hofstadter, "The Paranoid Style in American Politics," Harper's, November 1964, 77-86. Hofstadter's essay traces how "a sense of heated exaggeration, suspiciousness, and conspiratorial fantasy" runs through nearly two centuries of United States history (77). Then U.S. Senator Daniel Patrick Moynihan linked JFK directly to Hofstadter's concept, claiming the movie "could spoil a generation of American politics just when sanity is returning." Moynihan, "The Paranoid Style," Washington Post, 29 December 1991, C1.

${ }^{8}$ See David Cook, Lost Illusions: American Cinema in the Shadow of Watergate (Berkeley: University of California Press, 2000), 197-205. For a thorough description of this genre and discussion of its connection to Stone's style, see Andrew Horton, "Political Assassination Thrillers," in A Political Companion to American Film, ed. Gary Crowdus (Chicago: Lake View Press, 1994), 310-18.

${ }^{9}$ JFK's percussive editing was compared to Eisensteinian montage, sometimes with explicitly musical terms, as with Frank Beaver's invocation of "rhythmic variation" and "metronomically charged images.” Frank Beaver, Oliver Stone: Wakeup Cinema (New York: Macmillan, 1994), 173.

${ }^{10}$ A full summary of the vociferous critical response to JFK is beyond the scope of this article. A synopsis is offered by James M. Welsh and Tom Prash in The Oliver Stone Encyclopedia, ed. James Welsh and Donald M. Whaley (Lanham, MD: Scarecrow Press, 2013), 113-14, and 289-98. 
argument for a massive conspiracy perpetrating and covering up the president's death. ${ }^{11}$

Nixon uses many of the same editorial techniques and paints a similarly paranoiac picture of the upheavals of the 1960s. However, compared to the generically fluid JFK, Nixon is a more traditional, if non-linearly structured, biopic. Scenes from Richard Nixon's youth are inserted at calculated moments within a biographical arc that traces the thirty-seventh president's rise and eventual fall from power. Although less of a cultural event than JFK at its release, Nixon too received a tempestuous reception, with volleys of criticism hailing from both right- and leftleaning commentators. ${ }^{12}$ Spared critical opprobrium was the universally praised Hopkins, who occupies the center of virtually every scene. No white knight such as Jim Garrison serves to champion the telling of truth to power. Unlike JFK, Stone's Nixon plays like a modern-day classical tragedy, with all its focus centered squarely on its ill-fated central character. An expressionistic visual vocabulary and a few outright allusions make a case for interpreting the film as a revisionist Citizen Kane (1941). ${ }^{13}$ One might go so far as to imagine Anthony Hopkins as a different take on Charles Foster Kane, had he happened to make it all the way to the White House. ${ }^{14}$

Serving the director's mythical and polemical ends are the film's musical scores, each penned by three-time Stone collaborator John Williams. ${ }^{15}$ Williams's initial association with Stone came through scoring Born on the Fourth of July (1989), a biopic on the life of Ronald Kovic, a Vietnam veteran turned anti-war activist. The sweeping orchestral soundtrack for July anticipates some of the stylistic features of JFK and Nixon: solo trumpet as lone voice of dignity, consonant strings and winds for the warmth of domestic American life, dissonant synthesizers underscoring

${ }^{11}$ Adam Baker critiques Stone's film for excess manipulativeness and moral clarity compared to generic predecessors such as The Parallax View and The Conversation. Adam Baker, "Cries and Whispers," in Sight and Sound 1, no. 10 (February 1992): 24-25. Stone himself has rarely acknowledged any stylistic debt to particular American films, more frequently pointing to lesser-known European thrillers like Z (1969), and The Mattei Affair (1972). See Gavin Smith, “The Dark Side," in Sight and Sound 6, no. 3 (March 1996), 6-9.

${ }^{12}$ For a summary of Nixon's ambivalent critical reception, see Norman Kagan, The Cinema of Oliver Stone (New York: Continuum, 2000), 264-69.

${ }^{13}$ The Orson Welles/Oliver Stone pairing is drawn explicitly and explored in depth in Philip L. Gianos, Politics and Politicians in American Film (Westport, CT: Praeger, 1998), 184-88.

${ }^{14}$ Frank Beaver goes so far as to claim "the music from Nixon borrows familiar motifs from Bernard Hermann's [sic] score for Citizen Kane." See Frank Beaver, “'Citizen Nixon': Oliver Stone's Wellesian View of a Failed Public Figure," in The Films of Oliver Stone, ed. Don Kuntz (Lanham, MD: Scarecrow Press, 1997), 275-84. Direct borrowing is almost certainly an overstatement, although a possible link exists between the Dies Irae referents that serve as motivic wellsprings in both scores; note, for example, the conclusion of "Motif L" in example 4 of this article. Many other instances share Herrmann's gothic affect if not sound, such as Nixon's title cue (especially at 0:4:40-0:5:10). See also William Rosar, "The Dies Irae in Citizen Kane," in Film Music: Critical Approaches, ed. Kevin J. Donnelly (New York: Continuum, 2001), 103-66.

${ }^{15}$ Little scholarship presently exists on Oliver Stone's use of music. One important offering is Jason Hanley's essay, "Natural Born Killers: Music and Image in Postmodern Film," in Postmodern Music/Postmodern Thought, ed. Joseph Auner and Judith Lochead (New York: Routledge, 2002), 33560. Hanley argues that Stone's use of music in Killers adheres to the same post-modern aesthetic that marks his visual language, employing collage and juxtaposition to destabilize meanings and suggest new ones. Although less overtly, JFK and Nixon subject Williams's scores to many of the same fragmentary processes. 
the questionable activities of the United States during the 1960s and 70s. In some ways, JFK is a much closer cousin of its predecessor July than it is to Nixon. ${ }^{16}$ Their narratives follow traditional redemptive heroic arcs: a male protagonist is gradually disillusioned by socio-political horrors of the 1960s, risks severed ties with family members, but is ultimately vindicated by his devotion to Truth. Nixon, by contrast, forcefully denies its central character a righteous ending, and the truth he stumbles upon on the eve of his downfall is of a purely personal, not socially transformative sort. This specific contrast strongly affects the musical scores, as will be discussed shortly. In any case, Williams brought a well-developed personal lexicon of musical codes_-Williamsisms," one might say-to JFK and Nixon. The resultant creative consistency is one obvious means by which the two films come to form a linked politico-aesthetic unit, both invested in manufacturing the sonic component to Stone's historical metanarratives. ${ }^{17}$ And because the collaboration between Stone and Williams is so circumscribed (only three films of the director's twenty-three), it is difficult not to hear JFK and Nixon as a significant musical pairing.

In this study, I explore the colors with which Williams paints the portraits of these significant figures and how music serves Stone's larger goals of mythologizing the recent past and musicalizing national political trauma. I begin by putting Stone's political aesthetics in context. That leads to a discussion of musical style as it informs the (counter)myth-making behind JFK and Nixon. I follow with an examination of the scores' construction of political villains ("The Beast") and heroes (JFK, Jim Garrison). I conclude with a close reading of Richard Nixon's thematic material and the accompaniment of his speeches; Williams's characterization of Nixon, I claim, positions him as simultaneously occupying the mythic roles of hero and villain.

Throughout, I illustrate how Williams's underscore immerses the filmgoer thoroughly within the treacherous currents of Stone's version of history. ${ }^{18}$ Sometimes in conflict with the immersive aim, however, Williams's music also enables reflection on past presidencies at a critical distance. Williams thereby falls within a legacy of executive portraiture whose musical artists include several of his stylistic models,

${ }^{16}$ Parts of Born on the Fourth of July are strikingly redolent of the lyrical first two movements of Barber's Violin Concerto. Whether this link was the result of Williams's preexisting admiration of Barber or the film's assigned temp-track, it continues the trend of transmuting Barber's music into underscore that marks Delerue's score to Platoon as well.

${ }^{17}$ For reasons that are unclear, since Nixon, Stone has not made use of Williams's pen. Prior to July, Stone collaborated with French composer Georges Delerue, who wrote scores to Salvador (1986) and Platoon (1986), the latter largely overshadowed by Stone's use of Samuel Barber's "Adagio for Strings." Stewart Copeland (best known as the drummer for The Police) provided music with contemporary synth and popular sounds for Stone's next two movies, Wall Street (1987), and Talk Radio (1988). The final film in the "Vietnam Trilogy," Heaven and Earth (1993), was scored by Japanese composer Kitarō and relies much more heavily on non-Western styles of varying degrees of authenticity.

${ }^{18}$ By focusing on Williams's orchestral underscore, I do not wish to give the impression that only non-diegetic music participates in the mythopoetics of these films. For example, the president's penchant for piano playing features in a key scene in Nixon, while excerpts from Mozart and Brent Lewis's percussive world music variously suggest urbanity and indecency for the world surrounding Clay Shaw in JFK. Further discussion of diegetic music is outside the scope of this article. 
such as Ives, Copland, Harris, and Adams. ${ }^{19}$ As will become evident, JFK and Nixon are the two most political of Williams's soundtracks, thereby offering a study in the reconciliation of presidential reality and myth, history-as-fact and history-asmetanarrative. ${ }^{20}$

\section{Stone's Political Aesthetics}

Before delving fully into the musical mythopoetics of these two films, it will be useful to have a sense of Oliver Stone's political and cinematic philosophies, and how they influenced his collaboration with Williams. Throughout his directorial career, Stone has returned compulsively to subjects of post-war American history, leading some to label him a "cinematic historian." ${ }^{21}$ Informed by his disillusioning experiences as an infantryman in Vietnam and propelled by a flair for radical politics, Stone wields the elements of filmmaking as tools to jostle audiences into a more alert, critical engagement with their past. As Marita Sturken puts it,

Stone has, perhaps more than any other producer of popular culture, attempted to interpret, narrativize, and make meaning of late twentieth-century American history. As a consequence of his ideological stance, his position as a popular historian, and his particularly dogmatic style of filmmaking, he has been a figure upon whom tremendous hostility and anxiety have been projected. ${ }^{22}$

No two films elicited more hostility (or, in equal measure, appreciation and fascination) from critics, historians, and politicians than JFK and Nixon. ${ }^{23}$ The director saw the movies as a linked and coherent statement on the politics of the 1960s and their aftermath. With Kennedy as "prologue" and Nixon "epilogue,"

${ }^{19}$ See David Thurmaier, "Ives and Lincoln, The Great Commoners?" (paper given at the annual conference of the Society for American Music, Lancaster, PA, March 2014); Elizabeth Bergman Crist, Music for the Common Man (Oxford: Oxford University Press, 2005); Malcolm D. Robertson, "Roy Harris's Symphonies: An Introduction," Tempo 207 (December 1998): 9-14; and Timothy Johnson, John Adams's Nixon in China: Musical Analysis, Historical and Political Perspectives (Burlington, VT: Ashgate, 2011). Lesser-known works in this tradition include Daniel Gregory Mason's Third Symphony, "Lincoln," and Jaromir Weinberger's "Lincoln Symphony."

${ }^{20}$ John Adams's opera Nixon in China (1987) might seem the most relevant point of comparison with the score of Nixon, but no obvious musical linkage of any sort is discernible between the two works. What is shared is a similar interest in converting the Nixon administration into the stuff of myth. See Daniel Frick, Reinventing Richard Nixon (Lawrence: University Press of Kansas, 2008), $175-79$.

${ }^{21}$ Stone initially emphatically resisted this term, although commentators have found the description apt. See Robert Rosenstone, "Stone as Historian," and Oliver Stone, "Stone on Stone's Image (As Presented by Some Historians)," in Oliver Stone's USA: Film, History, and Controversy, ed. Robert Brent Toplin (Lawrence: University Press of Kansas, 2000), 26-39 and 40-65.

${ }^{22}$ Marita Sturken, "Reenactment, Fantasy, and the Paranoia of History," History and Theory 36, no. 4 (1997): 65.

${ }^{23}$ Stone's presidential trilogy would conclude with W. (2008), a biopic on George W. Bush, released at the cusp of his successor Barack Obama's election. $W$. surprised critics with its relative conventionality and sympathy toward its polarizing and unpopular subject. See Kingsley Marshall, "Stone's Improbable W.," in Presidents in the Movies, ed. Iwan W. Morgan (New York: Palgrave Macmillan, 2011), 171-91. The original music is an innocuously reflective score by Paul Cantelon, generally overshadowed by motivic use of preexisting music, notably an unironic deployment of "The Yellow Rose of Texas." 
together these presidencies would act as framing devices to "understand our country in those turbulent years." 24

An overview of Stone's filmography and written and spoken statements reveals that the director's political aesthetics are both complex and frustrating, the product of multiple, sometimes seemingly contradictory attitudes toward history and narrative. Stone has a radical skepticism toward the possibility of completely accurate or impartial accounting of the past. In interviews, he has consistently and aggressively rejected what could be termed history-as-fact. ${ }^{25}$ Yet despite his contempt for objective historiography, he also has an archivist's zeal for extensive research and voluminous citation of data and opinion. ${ }^{26}$ Stone's entire filmography betrays a polemicist's urge for countering prevailing and official accounts of the past. At the same time, he holds a mythologist's commitment to the existence of grand narratives and the truths that lie behind things. Many of his films in fact embrace a totalizing style of history-as-metanarrative, a stance that runs counter to postmodernist intellectual currents of the late twentieth century. ${ }^{27}$ Together, these last two factors - the instinct for contrariety and the mythmaking - contribute to the central theme of "countermyth," which we shall explore in more detail at the end of the next section.

Stone's movies ultimately strive to offer emotional catharsis and intellectual clarity. He achieves them through the act of selecting and converting historical data into simplified, moralizing narratives. This is this sense to which his films are so frequently referred to-by critics and the director himself-as mythic in structure and purpose. ${ }^{28}$ They make no claim to the chimerical goal of neutral recounting of fact, and instead employ cinematic devices to rhetorical ends. ${ }^{29}$ Chronology may

${ }^{24}$ Oliver Stone, “On Nixon and JFK," in Oliver Stone's USA, 255.

${ }^{25}$ Stone sometimes articulates his subjectivist philosophy of history bluntly (verging on absolutist naïvety): "What is history? Some people say it's a bunch of gossip made up by soldiers who passed it around a campfire. ... The nature of human beings is that they exaggerate. So what is history? Who the fuck knows?" Quoted in Robert Sam Anson, "The Shooting of JFK," Esquire, November 1991, 93.

${ }^{26}$ Stone, put thoroughly on the defensive at JFK's release, published a massive Book of the Film (New York: Applause Books, 1992), which included the complete screenplay, annotated throughout with reference to primary sources supporting the script's historical license. The cataloger's instinct is evident in this same volume with the inclusion of nearly one hundred reviews and editorials on the film, both positive and negative. In anticipation of Nixon's release Stone would publish a similar book (Hamburg, ed., Nixon: An Oliver Stone Film), full of historical documents plus the movie's screenplay.

${ }^{27}$ On Stone's paradoxical stances toward history, see Susan Mackey-Kallis, Oliver Stone's America: "Dreaming the Myth Outward" (Boulder, CO: Westview Press, 1996), 7-32. This aspect of his filmmaking has also come under heavy critique. According to Baker, in translating American history into a series of "heroic quests," Stone is guilty of "a remarkable naiveté about cinema's ability to present 'the truth."” Baker, "Cries and Whispers," 25.

${ }^{28}$ Mackey-Kallis identifies Stone's metanarrative as a postlapsarian view of American history, of a nation that recurrently sacrifices its innocence: “The central myth running through Stone's work is that of the fallen idealist/savior ... killed, maimed, or disillusioned in a seemingly senseless sacrifice... The 'fall' of these saviors represents America's loss of innocence, while the halfhearted resurrection offered by and to many of them represents, on one level, a sinfully unredeemable America... On another level, however, Stone's archetypal heroes, willing to live life in the extreme, ... offer the only hope for transcendence." Mackey-Kallis, Oliver Stone's America, 10-11.

${ }^{29}$ The assumption of the label "myth" implicitly sets Stone's films against its opposing generic category of the documentary, a format distinguished by its (of course impossible) aspiration to realism, objectivity, and neutrality. Stone co-opts many of the documentarian's techniques, particularly in JFK, 
be manipulated, characters conflated, facts massaged, altered, or even invented, so long as they contribute to a more clear picture of the storyteller's core narrative. "Filmmakers make myths," Stone avers. "They take the true meanings of events and shape them." 30

Ultimately, Oliver Stone's presidential films are concerted attempts to construct and refine a myth of the American 1960s. In JFK, Stone argues that the innocence and heroic promise Kennedy represented are destroyed from without by the malevolent force of the military-industrial complex, a foe challenged bravely but ineffectually by devotees of the "Truth." This intangible antagonist is referred to in Nixon in abstract (and eschatological) terms as "the Beast." There, it also brings about the downfall of the title character, albeit as a corrupting force internalized in the president, both hero and antagonist within his own narrative. Stone's Nixon provides a dark inversion of the myth of the American dream. Merit and struggle are not sufficient to place him at the top: concessions to "the Beast" are required at every turn, ultimately leading to his moral and political collapse.

\section{Williams's Mythic Americana}

John Williams is no stranger to "scoring presidencies," nor indeed American politics at large. Given his Academy Award-nominated score to Born on the Fourth of July and stature as the U.S.'s most prominent symphonic film composer, he was an obvious choice for Stone's presidential dramas. ${ }^{31}$ However, with respect to musical style and political sensibility, Williams is an unusual match for the director. The most Oscar-nominated living person is by no means a political composer, in fact being conspicuously and consistently reticent in interviews to speak on matters of policy, ideology, or social controversy. He is certainly not political in the same sense as some of his predecessors such as Hanns Eisler and Aaron Copland-composers who, like Williams, composed for both concert stage and screen. ${ }^{32}$ In the few places where the musicological literature has waded into the issue of Williams's musical politics, it has focused chiefly on strains of nostalgia and/or stylistic conservatism evident in Williams's trend-setting orchestral scores for genre pictures of the 1970s, seen by many commentators as explicit throwbacks to classical Hollywood practice. ${ }^{33}$ Yet it is in soundtracks like JFK and Nixon that we can find expressions of a more deliberate

but they are always in service of erecting sweeping socio-mythical arguments rather than allowing image and sound to speak for themselves.

${ }^{30}$ Quoted in David Ansen, "What Does Oliver Stone Owe History?" Newsweek, 23 December 1991, 49. Never reticent about the magnitude of his ambitions, Stone encourages comparison with other literary myth-weavers. "I consider myself a person who's taking history and shaping it in a certain way. Like Shakespeare shaped Henry V." Quoted in Anson, “The Shooting of JFK," 102.

${ }^{31}$ Pressed for funding, Stone had to fight with Universal Studios bankrollers to have Williams lend his prestige and what Stone called "heart" to Born on the Fourth of July. Universal ultimately relented, and Williams earned July a best-score Oscar nomination (as did JFK and Nixon). See James Riordan, Stone (New York: Hyperion, 1995), 301.

${ }^{32}$ See, for example, Sally M. A. Bick, "Composers on the Cultural Front" (Ph.D. diss, Yale University, 2001); and Emily Abrams Ansari, "Aaron Copland and the Politics of Cultural Diplomacy," Journal of the Society for American Music 5, no. 3 (2001): 335-64.

${ }^{33}$ For a balanced take on Williams's stylistic retrospection, see Mervyn Cooke, A History of Film Music (Oxford: Oxford University Press, 2008), 456-66. 
and perhaps even incisive political attitude, as milestones in the composer's larger pattern of engagement with the office of commander in chief.

Like a musical Aaron Shikler, Williams has been producing a gallery of presidential portraits for decades. The cinematic depictions include, notably, many partnerships with Steven Spielberg: take, for example, the music attached to John Quincy Adams in Amistad (1997); Abraham Lincoln, in Lincoln (2012); and Lincoln again (by proxy) in Saving Private Ryan (1998). Living politicians, Democrats in particular, have also used Williams's prominence in American culture. ${ }^{34}$ Williams wrote occasional pieces for Michael Dukakis (Fanfare for Michael Dukakis, performed at the 1988 Democratic National Convention), and Barack Obama (Air and Simple Gifts, performed at the 2008 inauguration; A Timeless Call for Spielberg's short film at the same year's party convention; and "For The President's Own" in 2013). ${ }^{35}$ And though not by the composer's devising, an arrangement of main theme for the film The Patriot (2000) was played during Obama's speech in Chicago on the night of his 2008 victory. ${ }^{36}$

A common thread in these compositions and others that project national pride is their sparking orchestration and consonant melodiousness-with allowances for the occasional non-disruptive dissonance. ${ }^{37}$ The model for much of this "Americana style" and the musical topics that infuse it is undoubtedly Copland. ${ }^{38}$ The Coplandesque "pastoral trope," as Neil Lerner identifies it, has been a resilient constant in Hollywood film scoring since the 1940s. Many of the topics Lerner attributes to this style can be located throughout Williams's Americana works, even when they are concealed by the composer's more chromatic and leitmotivic personal style. ${ }^{39}$ Tonic pedals undergird the slow diatonic chorale in the Omaha Beach segment from

${ }^{34}$ Williams's involvement in political campaigns and his public record campaign donations suggest firm placement on the left side of the political spectrum. See "Newsmeat: Federal Campaign Contributions Since 1978, John Williams," http://web.archive.org/web/20130117210739/http://newsmeat. com/celebrity_political_donations/John_T_Williams.php. That a left-leaning composer could contribute to films that more than a few commentators have shown to be problematically regressive is one of the paradoxes of artistic expression and commercial exigency in Hollywood.

${ }^{35}$ No recording or in-print score of the Dukakis fanfare exists, although a performance may be heard online at http://www.c-span.org/video/?c4453714/john-williams-fanfare-michael-dukakis.

${ }^{36}$ See Katharine Q. Seelye, “Seeking the Proper Tone for Obama’s Inauguration,” New York Times, 9 December 2008.

${ }^{37}$ Pieces written in the same vein include Williams's "Liberty Fanfare" (1986) for the Centennial celebration of the Statue of Liberty; "Hymn to New England" (1987) for Mugar Omni Theater at the Boston Museum of Science; “American Journey" (1999) for the Millennium New Year's eve celebration in Washington D.C.; and a widely broadcast bicentennial arrangement of the "Star Spangled Banner" (2014).

${ }^{38}$ See Neil Lerner, "Copland's Music of Wide Open Spaces: Surveying the Pastoral Trope in Hollywood," Musical Quarterly 85, no. 3 (2001): 477-515. Lerner remarks on Williams's usage of the trope that "pastoralism functions in traditional ways: to evoke a utopic space, accompanying characters defined by their self-sacrifice in the service of a common good" (505-6). Williams's eclecticism makes it difficult to pin down only one composer as inspiration for his Americana style (or genre-blues, gospel, jazz, and bluegrass leave their marks as well). Indeed, one might well add Howard Hanson, Leonard Bernstein, and John Philip Sousa as concert composers whose fingerprints can be felt on Williams's specifically presidential style.

${ }^{39}$ Williams's debt to Copland is most plain in Air and Simple Gifts, whose lyrical reworking of the Shaker melody from Appalachian Spring was inspired by Obama's own predilection for Copland. A further, more political linkage to the Lincoln Portrait is referred to in Jon Burlingame, 
Saving Private Ryan. Wide intervals and equally wide orchestral voicings suggest the fertile expanses of the West in The Cowboys (1972) and Superman (1978). Brass discant full of perfect fourths and fifths straight out of Fanfare for the Common Man lends politicians the appropriate gravitas in Lincoln and Amistad. Aside from Copland, the broad appeal of this music recalls nothing so much as the art of Norman Rockwell.

Oliver Stone's political radicalism and technical experimentation might thus seem in conflict with Williams's generally accessible and non-experimental musical temperament, as epitomized in his Copland-referring Americana style. ${ }^{40}$ Nevertheless, their working relationship was by all accounts a smooth, productive, and mutually admiring one. ${ }^{41}$ One immediate upshot of the collaboration is an exploitation of Williams's facility with modernist idioms. As we will see, the more modern compositional techniques that occur in JFK and Nixon tend to entail a selective pressuring (although not rejection) of the nostalgic tendencies in Williams's symphonic style. The scores' tonal and timbral idioms do nod on occasion to the pastoral dialect that one suspects is the composer's default symbolic modus. But just as often, they delve into dissonant and aloof sound-worlds, resistant to long lyrical lines, willing to dabble with Coplandesque nobility but heavily skeptical of the comforts of (pan)diatonicism.

Unlike his optimistic compositions for other presidents, Williams's JFK and Nixon eschew brassy, extroverted pomp. Musical codes associated with distress or conflict (dissonance, dense polyphony, electronics) are given consistently higher prominence. The Americana music that does appear-which includes some musical topics less indebted to Copland, such as military drum rhythms-often exists in order to be disrupted or dismantled. Consonance is only rarely left uncontested by the more dystopic elements of the soundtrack. ${ }^{42}$ The two scores do not establish this dichotomy in an entirely equivalent fashion. JFK shares with July a strategy of positioning consonance and melody as a kind of musical originary state, lost or corrupted in most of the score, but ultimately recovered through righteous

\footnotetext{
“Williams' Music for Obama’s Ears," Variety 29 January 2009, http://variety.com/2009/music/news/ williams-music-to-obama-s-ears-1117998645/.

${ }^{40}$ The composer was best known in the late 1980s and early '90s for his scores for blockbusters aimed at children and the young at heart. The divergence in aesthetic personalities between Williams and Stone is highlighted by comparison of Stone with another director long associated with Williams: Steven Spielberg. With a few exceptions, Spielberg's sentimental and fantastical films bring out Williams's musically more retrospective side, as typified recently by the well-crafted, fundamentally consonant, and old-fashioned scores for Lincoln and War Horse. Lerner critiques Williams's music for Close Encounters of the Third Kind for participating in a reactionary musical aesthetic, stating that the score takes a "child-like perspective... [that] reassures, persuades, and above all else, lulls us into being uncritical." See Neil Lerner, "Nostalgia, Masculinist Discourse and Authoritarianism," in Off The Planet: Music, Sound, and Science Fiction Cinema, ed. Philip Hayward (Bloomington: Indiana University Press, 2004), 96-109.

${ }^{41}$ Williams and Stone went out of their way to praise each other in many interviews. See, for example, Richard Dyer, "You'll Be Hearing From Him," Boston Globe, 31 August 1989; and Yann Merluzeau, “An Interview with John Williams," Soundtrack! 12, no. 41 (September 1993): 8.

${ }^{42}$ One pertinent model for the strategic mixture and distortion of patriotic musical topics in mainstream film would be Jerry Goldsmith's influential score for Patton (1971), although Williams's own dabbling in this compositional mode can be heard as early as the war drama None But The Brave (1965).
} 
sacrifice. (JFK even allows its musical Americana to surge splendiferously during its final scene, shorn of irony or ambiguity). By contrast, it is the darkness that Nixon's score always returns to, making those few moments where melody and tonal stability assert themselves sound suspect.

Although the musical idiom Williams employs in JFK and Nixon may not recall the musical Rockwellianism of his other Americanist projects, one crucial aspect does place them firmly within the composer's accustomed area of expertise: myth-making. Williams's best-known scores (and many lesser-known ones) evince a mythologizing impulse widely noted in both critical and musicological discourse. ${ }^{43}$ To a certain extent, the composer's inclination towards larger-than-life symphonic scoring may just be an especially aggressive manifestation of realityheightening tendencies always active in mainstream film. But in Williams's intentionally mythic scores, the orchestra magnifies mundane events into epochal turning points and turns actors working from scripts into walking Jungian archetypes. His music smoothes over narratival inconsistencies and frames scattered scenes into absorbing — and often simple, highly familiar-narratives.

Williams's talent for musical mythmaking would thus be a great asset to Stone, whose own interest lay in formulating myths rather than neutral accounts of history. The American cultural mythology that Stone endeavors to construct in JFK and Nixon is motivated by two storytelling urges: the first a need to process national trauma, the second a desire to offer a response to prevailing narratives. The rehearsal of trauma through filmic reconstruction and repetition helps cement the perpetual "nowness" of Stone's version of the past, solidifying a sense of urgency-and inescapability—of elements of American identity he chooses to dramatize. John Hellmann points to Stone's obsessive reiteration of a few horrible frames from the Zapruder film in JFK as part of a kind of Holy Communion:

\begin{abstract}
The authority of the Zapruder film is that of an undeniable fact transfigured into collective rite. We suffered the loss of Kennedy in history, but it has become a religious experience through the collective pain we continue to experience in it. Stone's repetitive use of the home movie makes it a ritual. As we return to the moment of assassination many times in the course of JFK, our re-viewings join us with Garrison/Costner as our surrogates in this suffering. ${ }^{44}$
\end{abstract}

Like Kennedy's portrait louring over Anthony Hopkins, Stone's history becomes an indicting ghost, demanding more than mere remembrance or neutral retelling. Williams's reliance on well-established style topics, as well as other techniques we will soon explore such as repetition and monumentalization, makes these films all the more portentous and direct in their messages. If Williams's sometimes-elegiac

\footnotetext{
${ }^{43}$ James Buhler offers a penetrating analysis of the formal and ideological resonances of Williams's leitmotivic scores for Star Wars in terms of mythology. Buhler, "Star Wars, Music, and Myth," in Music and Cinema, ed. James Buhler, Caryl Flinn, and David Neumeyer (Hanover, NH: Wesleyan University Press, 2000), 33-57. He observes the occasional (echt-Wagnerian) free-floating, contra-linguistic nature of Williams's leitmotifs, noting that "the music seems to intuit connections that are beyond immediate rational comprehension” (44).

${ }^{44}$ John Hellmann, The Kennedy Obsession (New York: Columbia University Press, 1997), 159.
} 
accompaniment provides a counterpoint to Stone's raw outrage, it nevertheless does so according to the same drive to relive tragedy and ritualize trauma. ${ }^{45}$

The moral shadings of Williams's music-hyperexplicit in JFK and strategically ambiguous in Nixon - also aid Stone's desire to reveal "untold" aspects of history. The director's sense that the American public had not accepted or satisfactorily scrutinized the Warren commission accounts for his insistence that JFK is a "countermyth." 46 This insistence on the mythical status of his film is not merely an escape clause for the numerous, sometimes flagrant liberties taken with historical fact. For $J F K$, Stone offered the following rationale:

In the end, the importance of a historical episode is not just its factual content but its emotional and ethical significance as well. Why did it happen? What does it mean? ... This process of evaluation, when undertaken by a whole society, eventually leads to the creation of a cultural myth. ... [M]yths have always expressed the true inner meaning of human events. Myths are dynamic. They reinterpret history in order to create lasting, universal truths. ... With $J F K$, we are attempting to film the true inner meaning of the Dallas labyrinth - the mythical and spiritual dimension of Kennedy's murder-to help us understand why the shots in Dealey Plaza still continue to reverberate in our nightmares. ${ }^{47}$

Stone does not imagine himself as radical revisionist historian, but rather an almost atavistically reinterpretive historian. John Hellmann reads Stone's appeal to myth as a way of impressing "upon Americans that the interpretation of the facts carrying the authority of the establishment—-the government and national media-is not necessarily definitive." ${ }^{\text {8 }}$ By converting an assassination and a resignation into narratives of Manichean dimensions, Stone believed he could make these events more broadly intelligible, while at the same time dispelling decades of institutional deception, inveigling, and obfuscation. As Norman Mailer claims with regard to $J F K$, "tragedies of this dimension [of Kennedy's death] could only be approached as myths." ${ }^{49}$ With Americana tropes arrayed and ready for dismantling and reconstitution, Williams's music establishes the clean lines of Stone's overall mythic metanarratives. At their foundation, these scores are about providing a degree of emotional clarity-indeed comfort—even as the events that they paint horrify us still.

${ }^{45}$ Several commentators likened Stone to the artistic mythmaker and Gesamtkunstler himself, Richard Wagner (an obvious and acknowledged influence on Williams as well). Norman Mailer notes the "Wagnerian vein" of Stone's quest-like narratives, while Anson ("The Shooting of JFK," 93) and later Mackey-Kallis (Oliver Stone's America, 24) see Stone as "the Wagner of Hollywood," a prophetlike figure who "teaches his audiences through allegory and myth." See Norman Mailer, "Footfalls in the Crypt," Vanity Fair, February 1992, 124-29, 171.

${ }^{46}$ Oliver Stone, "Clarifying the Conspiracy," in Cineaste 19, no. 1 (1992): 25-27; and Stone, "On Nixon and JFK," in Oliver Stone's USA. Stone speaks of the lone gunman narrative as put forth by the Warren commission as a fabrication: "This is not history, this is myth. It is a myth that a scant number of Americans has ever believed. It is a myth that has sustained a generation of journalists and historians who have refused to question it, and above all who close ranks to criticize and vilify those who do" (Stone, "On Nixon and JFK," 293).

${ }^{47}$ Oliver Stone, "Oliver Stone Talks Back," Premiere, January 1992, 67-72.

${ }^{48}$ Hellmann, Kennedy Obsession, 158.

${ }^{49}$ Mailer, "Footfalls," 129. 


\section{The Beast}

Myths require antagonists. Williams frequently reserves his most insinuatingly memorable music for the enemy—Darth Vader, Captain Hook, Voldemort, Nazi henchmen, and so on. Yet without a concrete villain embodied within a single character in JFKor Nixon, Williams was compelled to take a more abstract approach than the usual catchy villain leitmotif. Instead, he stitched together Stone's presidential pictures with a set of recurrent timbres and techniques, consistent in their sound but stopping short of a coalesced "thematic portrait" for Stone's pervasive historical evils. There is no "Theme for the Military-Industrial Complex," nor could there be, given the screenplays' thesis of a centerless, elusive malignancy in American politics.

Set against the formless antagonist is an equally incorporeal protagonist: the image of John F. Kennedy. Despite bearing his name, the film JFK never features Kennedy as a character, only showing him speaking at the beginning of the film, his words culled from chopped-up newsreel footage. As Mark Feeney explains, Kennedy's "image is so potent that just invoking the name conjures up his presence." ${ }^{50}$ Kennedy the man and JFK the film haunt Stone's unofficial sequel as well. Anthony Hopkins's Nixon sees his predecessor as a real and, following his assassination, idealized political opponent-a constant point of comparison against Nixon's own embittered ego. Kennedy serves as a betrayed revenant who hangs over his successor's conscience. ${ }^{51}$ At times Stone's screenplay even suggests that Nixon was unwittingly and remotely involved in JFK's assassination. This contributes to a vague guilt towards what Anthony Hopkins, as Stone's mouthpiece, calls "The Beast"an uncontrollable adversary that emerges organically from the amalgamation of military, capitalist, and criminal interests. Hopkins's Nixon comes to see himself as just another pawn of this un-bridleable "Beast," powerless to stop the domestic and international tragedies of his administration. "Neither Marxist construct nor small cabal," explains Iwan W. Morgan, Stone's formulation of this mythic foe is "the representation of Darwinian forces in Cold War America." 52

Stone pulls no punches when it comes to the Beast's blood lust: "They [the CIA, urged on by then-Vice President Nixon] went after Castro, and in some crazy way it got turned on Kennedy," the film's version of H. R. Haldeman conjectures to John Ehrlichman. "I don't think the old man knows what happened. He's afraid to find out, I can tell you that. He's shitting peach pits every time he thinks about it" (2:35:00). Williams scores this conversation with a pair of nervous clusters ( $\mathrm{G} \#-\mathrm{A}-\mathrm{B} b$, and $\mathrm{C} \#-\mathrm{D}-\mathrm{Eb}$ ), set against a series of deep-nearly subaudible-bass drum strikes. In both JFK and Nixon, allusions to or manifestations of this "Beast" receive similar music to this scene. Recurrent colors include rumbling ostinati

${ }^{50}$ Mark Feeney, Nixon at the Movies (Chicago: University of Chicago Press, 2004), 329.

${ }^{51}$ The idea of Nixon as a "haunted" and/or "haunting" historical presence was persistent thread in some 1970s journalism, as is detailed and explored in Russ Witcher, After Watergate: Nixon and the Newsweeklies (Lanham, MD: University Press of America, 2000), 57-58.

${ }^{52}$ Iwan W. Morgan, "The President Impeached: Tennessee Johnson and Nixon," in Presidents in the Movies, ed. Iwan W. Morgan (New York: Palgrave MacMillan, 2011), 161. See also Donald Whaley, "'Biological Business-As-Usual': The Beast in Oliver Stone's Nixon," in Hollywood's White House, ed. Peter C. Rollins and John E. O’Connor (Lexington: University Press of Kentucky, 2003), 275-87. 
undergirded by synths, distorted fanfares, masked consonant melodies, and tight clusters. Especially characteristic is use of percussion in repetitive loops and low reverberations, both acoustic and electronic. ${ }^{53}$

The significatory power of these sounds relies on their ability to unsettle musical topics normally coded "noble" or "pure." In an interview on his scoring of Nixon, Williams explains the disturbance of diatonic music as a way of playing up the contrasts and paradoxes of Nixon's career, installing an almost antiphonal vacillation between heroic and tortured moods: "This side of the orchestra's playing along in a sort of consonant sort of way, where you have this kind of Shaker/Quaker American roots solidity. And suddenly something else happens on the other side of the orchestra which diffuses that, a dissonant element that comes in." "54 Williams's manipulations and disruptions of upstanding and "solid" Americana music helps expose the sickness that underlies Stone's view of American polity, a rot "at the heart of the American dream," as expressed by Kevin Costner at the end of JFK (3:08:20).

Snare drum lines and bass drum rumbles are particularly characteristic of "Beastly" percussion. Drum rhythms are used throughout JFK to invoke two topics: funeral processions and military marches. The former alludes to the drum corps at Kennedy's funeral, and the latter, more sinisterly, to the hypothesized military agenda behind the shooting. ${ }^{55}$ In Nixon, the American armed services' implied complicity with the tragedies of the 1960s is sublimated into nearly subaudible rumbles and crashes. Williams describes the unusual sounds in Nixon in almost apocalyptic terms:

\begin{abstract}
You have orchestral music that accompanies that very sinister atmosphere in the music. But electronically, you also produce some explosions that are kind of low-end booms. This kind of thing where you almost don't hear it but you feel it. Which is like a kind of napalm recollection of something in Cambodia that perhaps hadn't even happened yet. It's a kind of a pre-lap [a type of transition in film editing, also called a 'sound advance'] into the future and I think it can be very suggestive. ${ }^{56}$
\end{abstract}

As Nixon's sonic telltale heart, this muted musical metaphor quite literally "covers up" violence, leaving the carnage of war resonating faintly at the margins of the soundtrack. Rarely emerging to the aural foreground, Williams's beastly musical techniques generate an undercurrent of wordless unease that courses beneath both films. In JFK the musical manifestation of the Beast suggests undiscovered depths

53 The most pronounced use of "Beast" materials occurs during a lengthy exchange between Nixon and CIA director Richard Helms (1:34:00-1:44:50). A segment of the sequence features a cue from an outside music production company, not Williams himself, although subaudible "napalm recollections" remain an important part of the timbral palette. (See Nixon DVD, 3:31:11).

54 "Interview with John Williams" on Nixon DVD (0:15). Williams musically conflates Nixon's Quaker heritage with a musical image of Shakerism, the latter being a part of Williams's Americana style that manifestly draws from Copland's Appalachian Spring. The most unvarnished instances of these "American roots" materials come during scenes of Nixon growing up in Whittier, California.

${ }^{55}$ Stone offers this interpretation in his commentary on the JFK DVD (5:06).

56 "Interview with John Williams" on Nixon DVD (1:30). A similar sound is included in Williams's trailer music for Nixon, whose score calls for a "big, 'cosmic' Japanese drum" to be doubled with timpani and field drum. 


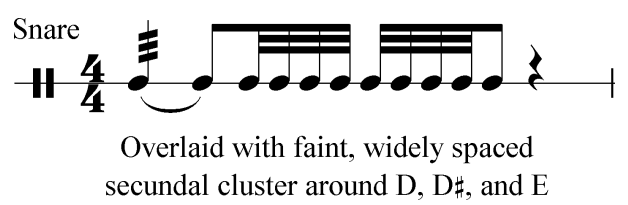

Example 2. The Drummer's Salute. From Nixon (1995, Cinergi Pictures Entertainment, Inc.), directed by Oliver Stone and produced by Dan Halsted, Eric Hamburg, Richard Rutowski, Oliver Stone, Clayton Townsend, and Andrew G. Vajna. Musical score by John Williams. Transcription by author.

of a conspiracy. In Nixon it intimates distant violence and buried presidential culpability.

The consistency of Beast timbres is emblematic of the abstract and figurative relationship between these two soundtracks, more so than any specific thematic recurrences, which are almost completely absent. Williams makes but one outright connection between the scores: a tracked statement of a snare drum rhythm (henceforth "The Drummer's Salute"), motivic in JFK, played during a mere tensecond span in Nixon (0:52:40, see example 2). Tiny though it is, this bit of recall is nevertheless highly pregnant. The Salute occurs within the scene where (an unseen) Kennedy lands at the Love Field airport in Dallas, a location from which, hours before, Nixon had departed. Immediately following this thematic reference, Anthony Hopkins learns news of the assassination. The fleeting motivic reminiscence thus stands in for the entire earlier score-and the lost president that the rhythmic gesture characterizes-while the moment of national trauma is experienced from Nixon's perspective.

\section{Devotion and Desecration in JFK}

The lack of thematic allusions between JFK and Nixon stems in part from the differing authorial process behind their soundtracks. Williams's music for JFK is unusual in having been composed prior to the completion of filming. It is a rare score engendered largely by personal reflection rather than spotting sessions or synchronization notes. The soundtrack for Nixon, by contrast, resulted from a more traditional (and protracted) approach to dramatic underscoring, which is apparent in the preponderance of synchronization points and the meticulous scoring of scene-to-scene transitions, among other things. ${ }^{57}$ This poietic difference yielded one score all about historical idealization and romanticized absence, and another that comes across as an effortful, "warts and all," sort of musical experience.

For JFK, Stone invited Williams to visit some of the historical locations where principal shooting on the film was just under way. Williams spent two weeks with Stone as the director shot in New Orleans and Dallas, including Dealey Plaza, the site of Kennedy's assassination. ${ }^{58}$ Drawing this geographical encounter together with his recollection of the day JFK died, Williams produced five large-scale,

\footnotetext{
${ }^{57}$ A post-compositional JFK-style music editing process is, in fact, evident at times in the score to Nixon, with cues rearranged and superimposed by whim. However, the extent of these manipulations is far less radical than in JFK and does not impart the same collage-like texture to the soundtrack.

${ }^{58}$ See Richard Dyer, "'Hook' and 'JFK' are Latest Hits with the John Williams Touch," in Boston Globe, 19 January 1992, A5.
} 


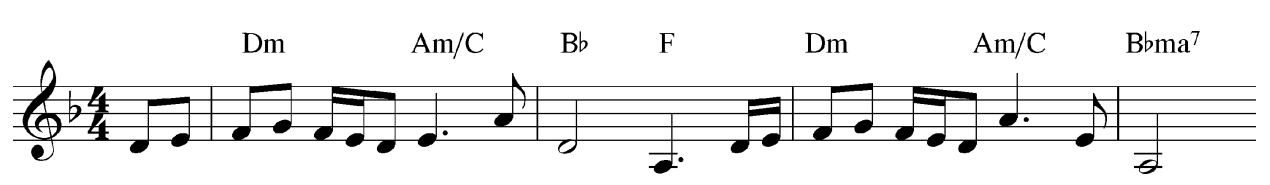

Example 3a. Heroic Materials-"Garrison Family Theme." From JFK (1991, Le studio canal and Regency Pictures), directed by Oliver Stone and produced by Oliver Stone, Arnon Milchan, and A. Kitman Ho. Musical score by John Williams. Transcription by author.

through-composed character pieces. ${ }^{59}$ Their subjects include "Arlington," "Garrison's Obsession," "Kennedy Theme," "The Conspirators," and "The Motorcade."60 Given the amount of music composed before shooting had concluded, Stone could claim that Williams "essentially had written the score before the film was finished." 61 This assertion is something of an exaggeration; these character pieces all together only account for twenty minutes of the hour of music in the movie (including numerous atmospheric diegetic cues). Along with subsequently written additional music, some based on the themes, these concert-performable works were edited, "cut up in a documentary fashion," and occasionally reused ad libitum in the film proper. ${ }^{62}$ Stone remarked that with the partially pre-editorial scoring style, Williams had "written a requiem in his head already." ${ }^{63}$ JFK's score was created through broad strokes by a composer with a personal stake in the represented subject, yielding a soundtrack infused with memory and imagination. Williams would later explain that his impressionistic approach was done to facilitate Stone's "documentary" film style of editing, but the result is anything but documentary-style authorial distance and effacement. ${ }^{64}$ The single-topic character pieces allow the complexities of history to fall away in favor of preordained musical narratives of American innocence, fallen heroes, and implacable and elusive enemies. In this sense JFK is the most mythic of all Williams's scores.

Melodic themes play a vital role in the characterization of both films' presidents. Nixon and JFK both garner flexible leitmotifs, although in the latter the various themes are functionally the same as the half-dozen "pre-cues" represented in example 3. JFK's recurrent melodic materials may be demarcated into two categories, consonantly tonal music for the heroic and domestic aspects of the film and "Beast" music. In the tonal category, "Garrison's Family Theme" (Example 3a) features a sentimental English horn melody; the choice of a double-reed instrument appears a consistent signifier in Williams's scores, connoting domesticity and parenthood in films ranging in genre from Stepmom (1998), Angela's Ashes (1999),

\footnotetext{
${ }^{59}$ For a brief discussion of the circumstances and editorial conception behind these character pieces, see Merluzeau, "Interview with John Williams," 5.

${ }^{60}$ Dyer, “'Hook' and 'JFK”, A5.

${ }^{61}$ See Jeremy Kagan, ed. and moderator, Directors Close Up (Lanham, MD: Scarecrow Press, 2006), 254.

${ }^{62}$ Dyer, "'Hook' and 'JFK', A5. Notably, selections and arrangements of these pieces are available as concert suites and have been performed on numerous occasions by Williams with the Boston Pops, Hollywood Bowl, and other orchestras.

${ }^{63}$ Kagan, Directors, 254.

${ }^{64}$ See Emilio Audissino, John Williams's Film Music (Madison: University of Wisconsin Press, 2014), 225.
} 


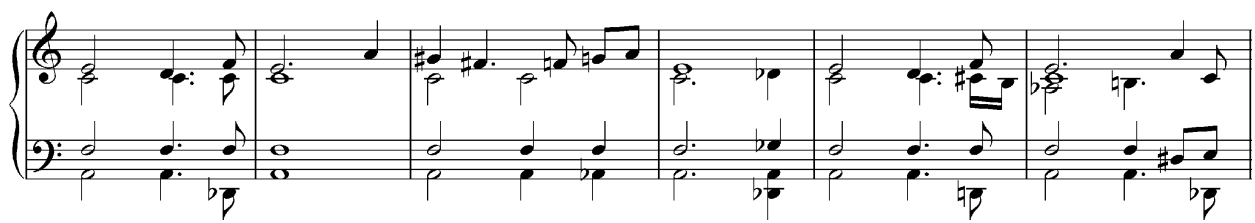

Example 3b. Heroic Materials-"Arlington." From JFK (1991, Le studio canal and Regency Pictures), directed by Oliver Stone and produced by Oliver Stone, Arnon Milchan, and A. Kitman Ho. Musical score by John Williams. Transcription by author.

and Star Wars: Episode I (1999) not to mention Born on the Fourth of July (1989). ${ }^{65}$ Functioning as an elegy, "Arlington" (Example $3 b$ ) is scored for string ensemble, instantly and opportunistically drawing from the deep associative well of its model, Barber's "Adagio for Strings," a work already closely linked in the American imagination with Kennedy's death. ${ }^{66}$ Through its connection with the film's visual motif of the Eternal Flame, Williams's musical devotional further cements its precursor's cultural association with public mourning and presidential loss. ${ }^{67}$

The most prominent piece in the consonant category is the "Prologue," alternatively the "Theme from JFK." The piece acts as an ostensible motto for the film, even though its quiet dignity hardly seems to fit with the subject matter of political corruption and historical fatalism. More than a "theme from," the piece serves as a "theme for"; that is, it is Williams's - and by extension Stone's—-memorialization of Kennedy himself. Musical monument-making of this kind serves Stone's project of portraying an idealized Kennedy, a promise rather than a person, whose personal identity may be smoothly filtered into a generic and inclusive American symphonic style. Williams's musical cenotaph is constructed from a veritable shopping list of codes for "Americana." The principal part of the theme (Example 3c) is supported by a stately diatonic accompaniment, while the melody above is full of wide-open intervals and a few, carefully calculated appoggiaturas and other expressive devices. Over the course of the film, the theme is variously intoned by strings, piano, and solo trumpet. ${ }^{68}$ Mixolydian-hued subtonic cadences and a lilting, metrically mixed

65 The family theme is ostensibly not one of the original five character pieces and is not mentioned in Dyer 1992, but as it appears on the original soundtrack album, it is a standalone, through-composed work nevertheless.

${ }^{66}$ On the Kennedys' fondness for the piece, and its pervasive use to memorialize JFK following his death, see Thomas Larson, The Saddest Music Ever Written: The Story of Samuel Barber's Adagio for Strings (New York: Pegasus Books, 2012). For an examination of the parallel streams of reception of the "Adagio," see Luke Howard, "The Popular Reception of Samuel Barber's "Adagio for Strings," American Music 25, no. 1 (2007), 50-80. For cinematic resonances of this piece, see David Bashwiner, "Musical Analysis for Multimedia: A perspective from music theory," in The Psychology of Music in Multimedia, ed. Siu-Lin Tan et al. (Oxford: Oxford University Press, 2013), 89-117.

${ }^{67}$ Williams-esque touches, such as the descending octatonic scale fragments and undulating harmonic rhythm sufficiently prevent "Arlington" from being a bald pastiche of "Adagio" in the manner of Delerue's music for Platoon, or, earlier, Alfred Newman's score for The Greatest Story Ever Told. These distinguishing elements also link it with one of Williams's few overtly personal compositions, the mournful second movement of his Violin Concerto (1976), written in memory of his deceased first wife.

${ }^{68}$ The trumpeter Timothy Morrison of the Boston Symphony Orchestra is Williams's go-to musician for distantly noble themes and is prominently featured on the soundtracks for Born on the Fourth of July, Nixon, Amistad, Saving Private Ryan, The Patriot, and other films. 

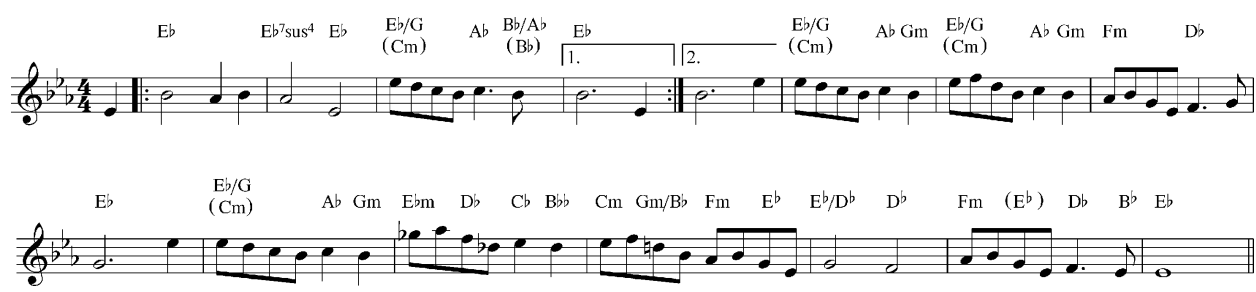

Example 3c. Heroic Materials-"Prologue" /"Theme from JFK" (conflated from several variants). From JFK (1991, Le studio canal and Regency Pictures), directed by Oliver Stone and produced by Oliver Stone, Arnon Milchan, and A. Kitman Ho. Musical score by John Williams. Transcription by author.

middle section full of Lydian touches lend it a passing modal quality. ${ }^{69}$ These harmonic and rhythmic traits are devised to evoke what Williams claims is a "reference to [Kennedy's] Irish ancestry." " It is worth noting that Kennedy's Irish roots have virtually no relevance within Stone's screenplay. But far from constituting filmic excess, the vaguely Celtic musical details simply activate an alternative set of codes that still play into the overall myth-making project. Instead of characterizing JFK's Arthurian nobility, the passing suggestion of folk musical elements helps tell a prototypical "immigrant story," the struggle to integrate into American society while retaining one's ethnic heritage. ${ }^{71}$

Williams has noted that "President Kennedy's life has always been imbued with a mythical dimension, no less powerful today than when he died." 72 This dimension is, of course, stronger after death. Posthumous mythification has been a steady refrain surrounding the thirty-fifth president, ranging in form the Greek tragedian's "family curse" myth to the Shakespearean "murdered rightful ruler" myth (the latter explicitly invoked by Stone).$^{73}$ Most powerful of all is the Camelot myth, in which the perfect heroic leader is made flesh for one brief moment. ${ }^{74}$ More than any other background narrative, it is this heroic narrative that Williams's "Theme for JFK" theme dutifully rehearses.

The fashion in which this melody accrues meaning over the course of the film is instructive as to Williams's larger mythic designs. The theme is first heard during JFK's prefatory montage, where a solo trumpet rendition accompanies footage of Eisenhower's farewell address. During this speech, the outgoing president famously warns against the growth of the military-industrial complex, immediately establishing the meta-antagonist of Stone's presidential films. However, the melody's "initial

${ }^{69}$ On associativity of modal cadences, particularly the "Americana"-coded subtonic cadence JFK makes poignant use of, see Frank Lehman, "Hollywood Cadences: Music and the Structure of Cinematic Expectation,” Music Theory Online 19, no. 4 (2013): http://www.mtosmt.org/issues/mto. 13.19.4/mto.13.19.4.lehman.html.

${ }^{70}$ See Williams's composer notes in JFK: Signature Edition (Milwaukee, WI: Hal Leonard, 1992). Williams's scores for Angela's Ashes (1999) and Far and Away (1992) enact a similar "Americanization" of Irish musical topoi. It is particularly vivid in the latter film, where Williams transforms several of the soundtrack's initially ersatz-Celtic leitmotifs into expansively orchestrated Coplandesque hoedowns and pastorales for the film's Oklahoma land rush set piece.

${ }^{71}$ On young JFK's negotiation of his Irish heritage, see Hellmann, Kennedy Obsession, 14-17.

${ }^{72}$ Williams, JFK: Signature Edition, [1].

${ }^{73}$ See Daniel Mendelsohn, “J.F.K., Tragedy, Myth,” in The New Yorker, 22 November 2013.

${ }^{74}$ This narrative was refined and promulgated especially by Jacqueline Kennedy following her husband's death. Hellmann, Kennedy Obsession, 145-46. 
baptism" - what Justin London, borrowing from philosopher Saul Kripke, dubs the moment when a motif attaches to its signified-occurs only with the next phrase, when it becomes clear JFK is himself is the symbolic target of the theme. ${ }^{75}$ At the very moment Kennedy is first shown (0:1:29), Williams's music swells: an effusive tutti version of the theme rings out as the narrator (Martin Sheen) extols the promise of Kennedy's new presidency, particularly his vision of global demilitarization. Stone's narrative hinges on the idea that JFK would have extricated the United States from Vietnam, and Williams's stirringly manipulative music leaves no doubt as to the honesty of such a promise - or, at the very least, the film's position that Kennedy held a genuine commitment to peace. ${ }^{76}$ At the end of the film, the same theme lends a triumphal air to Garrison's courtroom proceedings. It was a quest that ended in failure in legal terms, but within Stone's more important mythic coordinates, it is a resounding victory for having openly exposed "the truth." With the musical transference of the film's main theme from Eisenhower to Kennedy to Garrison, Kevin Costner's character assumes a special knowledge of the "Beast's" form and even absorbs a glint of the slain president's mythic glow. Garrison becomes all the more noble for suffering such an uncompromising defeat and is thus allowed to enter into a heroic historical space along with the fallen president. ${ }^{77}$

Set against these heroic musical markers, the other set of JFK associative material takes the form of aggressive and heavily repetitive music. Stone was especially pleased with these elements of the score and suggested that "Bernard Herrmann would be proud" of Williams's minimalistic suspense music. ${ }^{78}$ But although a certain Herrmannesque modularity is evident in JFK, William's style here owes at least as much to the influence of 1970s thriller scores from composers such as Jerry Goldsmith and Michael Small, who relied on angular piano lines, distorted Americana topics, and expressionistic use of electronics.

More than external compositional influences, however, Williams's manifestations of the Beast rely on world-music sounds to suggest villainy and perversion. The character piece "The Conspirators" (Example 3d), and subsequent cues that draw from it, conspicuously make use of Afro-Caribbean percussion. ${ }^{79}$ During scenes of plotting, both recounted and shown, claves and maracas lay down repetitive rhythms on top of which dissonant ostinatos and chordal oscillations assert themselves. The music for JFK's phantom antagonists thus relies, in part, on the

\footnotetext{
${ }^{75}$ Justin London, "Leitmotifs and Musical Reference in the Classical Film Score," in Music and Cinema, 87.

${ }^{76}$ The idea that, given a full term, Kennedy would have withdrawn from Vietnam was one of Stone's most fervently criticized surmises. See, for example, Alexander Cockburn, "Cockburn Replies," The Nation, March 9, 1992.

${ }^{77}$ On Stone's transformation of Garrison from a deeply flawed "historic individual to an artistic metaphor," see Anson, 93-102, 174-76.

${ }^{78}$ Stone, JFK DVD commentary (5:06).

79 "The Conspirators" was an influential piece of film music in the 1990s reworked in thrillers with similar suspenseful or mysterious plots. Examples include Under Siege (1992, comp. Gary Chang); The Firm (1993, comp. Dave Grusin); Jurassic Park (1993, comp. Williams); The Usual Suspects (1995, comp. John Ottman); Volcano (1997, comp. Alan Silvestri); and The X-Files (1998, comp. Mark Snow). Typical, perhaps, of Hollywood, the Afro-Caribbean percussive components from JFK remain in later examples, but for contexts totally divorced from their initial significatory rationale.
} 

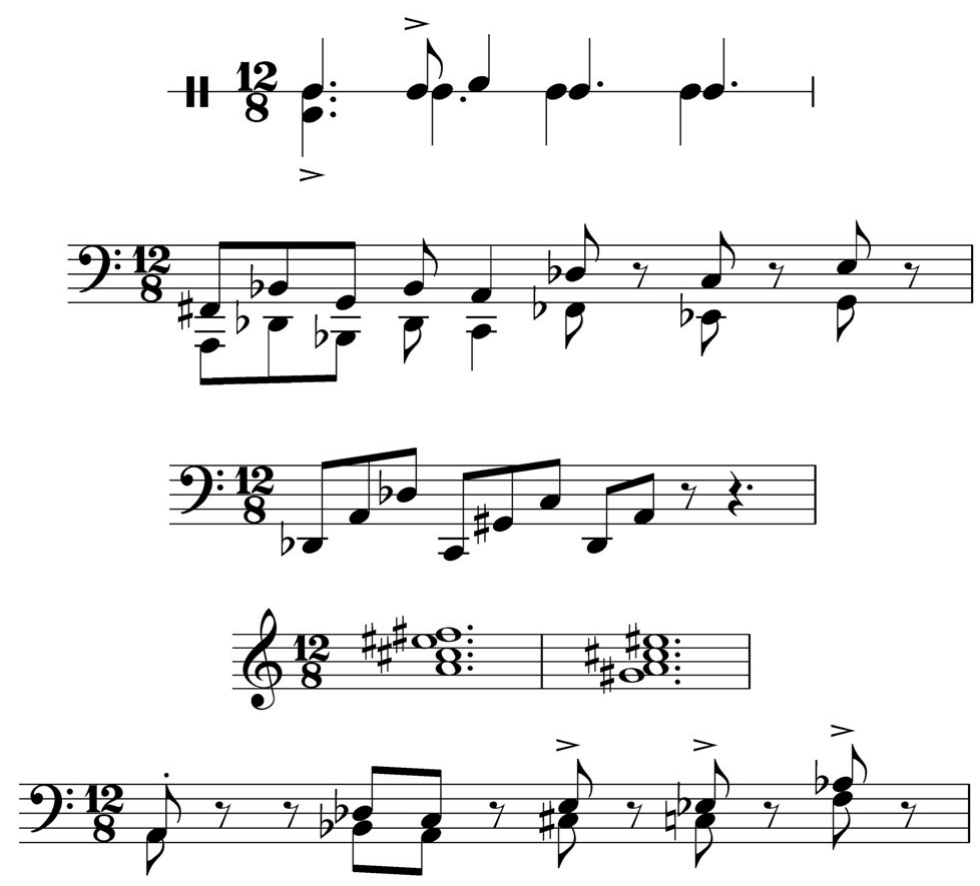

Example 3d. Beast Materials- "The Conspirators" particles. From JFK (1991, Le studio canal and Regency Pictures), directed by Oliver Stone and produced by Oliver Stone, Arnon Milchan, and A. Kitman Ho. Musical score by John Williams. Transcriptions by author.

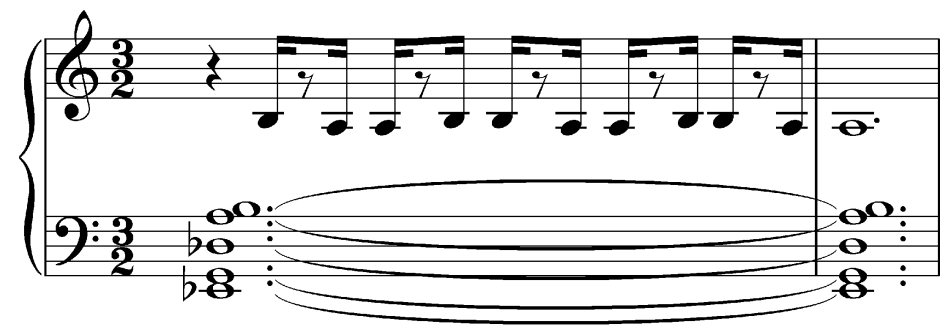

(This and similar clusters throughout)

Example 3e. Beast Materials- "The Motorcade." From JFK (1991, Le studio canal and Regency Pictures), directed by Oliver Stone and produced by Oliver Stone, Arnon Milchan, and A. Kitman Ho. Musical score by John Williams. Transcription by author.

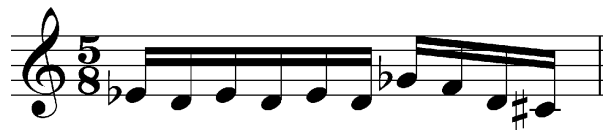

Example 3f. Beast Materials-"Garrison's Obsession." From JFK (1991, Le studio canal and Regency Pictures), directed by Oliver Stone and produced by Oliver Stone, Arnon Milchan, and A. Kitman Ho. Musical score by John Williams. Transcription by author.

projection of ethnic Otherness. This negative association is especially active for the radical ex-Cuban militants who, on Stone's account, were primary agents behind Kennedy's downfall; there are no "good" Cubans in JFK or "good" Cuban music. ${ }^{80}$

${ }^{80}$ Another source of music on the soundtrack is a set of three world percussion-heavy tracks, composed and performed by New Age/World Music percussionist Brent Lewis on his 1991 album 
Compounding the cultural problematics of Williams's conspiracy music, this already stereotyped "exotic" cue also fastens onto Stone's portrayal of a gay New Orleans subculture, in which Stone posits the assassination plot was initially fomented. ${ }^{81}$ Although not narratively unmotivated like the Irish elements of the JFK theme, the negatively valenced conspiracy music is part of a larger game of rigid moral and sexual contrasts in Stone's film, in which the all-American purity of the Kennedy/Garrison household is pitted against pretty much everything else. In Hellmann's interpretation of Stone's homophobic subtext, Kennedy, "the perfect man, the embodiment of the traditional ideals of masculinity" is destroyed by the "perverters of democracy," who "use a cabal of homosexuals to perform the violation of Kennedy's body with the assassin's bullets." ${ }^{2}$

Violation of body and ideal is mirrored by violation of musical material. Throughout JFK, Williams's theme for the president is cut up and subjected to a variety of splices, truncations, and maskings. While many of these forms of sonic desecration are the product of the editing process, others are built directly into the score. The first ten minutes of the film witness a steady and inexorable dismantling of the president's associated material. The trajectory of musical violence is represented in table 1 below. Williams and Stone first present the unvarnished "Prologue" without manipulation but progressively interrupt and destabilize it with spliced cues and menacing pedal points. As the moment of assassination nears, dissonant sounddesign completely overwhelms the last vestiges of JFK's melody. A final whimper of the theme (at 9:05) is foregrounded on the soundtrack as Walter Cronkite announces the president's death, but it is thoroughly unsettled by a set of gratingly dissonant pedals in both higher and lower registers.

In line with Stone's aesthetic of reliving trauma, the dramatization of Kennedy's assassination is repeated on several occasions from several dramatic angles in JFK. The climactic instance, which also features the most hostile attack on "JFK's theme" by the "Beast," takes place during the film's final courthouse scene. During Garrison's magic-bullet prosecutorial centerpiece, a long stretch of the character piece "The Motorcade" is heard (beginning at 2:52:35). Much like Stone's own montage style, the cue is based on a frenzied juxtaposition and near overwhelming barrage of acoustic stimuli. One hears disconnected fragments of the "JFK theme" in horns, "Drummer's Salute"-derived rhythmic ostinati, wailing bagpipes (another Irish connection), and wall after wall of clusters and polychords. Supporting it all is a pair of deep pedal points on the dyad $\mathrm{Ab}$ and $\mathrm{B} b$. These dissonant drones are drawn, perversely, from the melodic major-second alternation present in the main JFK theme itself, where it takes place between scale degrees 4 and 5. "The Motorcade" is thus a composite of differentiated and conflicting orchestral layers, a music of

Earth Tribe Rhythms. These too are associated on screen with the conspirators and further aid the film's musical conflation of radical right-wing politics, homosexuality, ethnic difference, and ethical depravity. Lewis's music was also featured in Stone's Natural Born Killers.

${ }^{81}$ The homophobic undercurrent in JFK was identified and denounced most vociferously by film critic David Ehrenstein, in "JFK-A New Low for Hollywood," The Advocate, 14 January 1992, 78-81. Stone responded to Ehrenstein's accusations and defended his artistic choices in a follow-up piece, Jeff Yarborough, "Heart of Stone," The Advocate, 7 April 1992, 44-49.

${ }^{82}$ Hellmann, Kennedy Obsession, 156. 
Table 1. Musical structure of JFK, first ten minutes.

Time Music

Event

0:0:23 Full "JFK theme" A section in Eb-maj (solo trumpet) against consonant Eb pedal plus "Drummer's Salute" snare rhythm.

0:1:30 "JFK theme" continued. Lush tutti tonal accompaniment, intermittent "Drummer's Salute."

0:2:09 Splice from "The Conspirators"; heroic thematic material absent.

0:2:57 "JFK theme" resumed. B section of theme in Eb (winds), consonant.

0:3:25 "JFK theme" continued. Full A section and contrapuntal elements of B theme in G-maj (strings, horns); followed by softer, more chromatic but still tonal ending of A section.

0:4:15 Fragmented theme in G-maj (strings, B section in winds) over dissonant low cluster on $\mathrm{Db}$ and Eb, plus intermittent "Drummer's Salute," premonitions of "Motorcade" motifs.

0:5:24 Full cue based chiefly on "Drummer's Salute" snare rhythm.

0:5:43 Snare music continued. "JFK Theme" in G-maj (low horns) against dissonant bass line (low strings), increasingly dissonant sound design.

0:6:45 Dissonant sound design takes over (sustained $\mathrm{G}+\mathrm{Ab}$ in multiple registers); music silence for moment of assassination, SFX of muted screams and birds flying following gunshots.

0:7:00 No music, some low rumbling ambient noise

0:7:24 Non-thematic section. Low, quietly loosely tonal string music, gathers over $\mathrm{D} b$ pedal. Quiet bass drum rumbles.

0:8:12 String music continues, atonal counterpoint intensifies, coalesces over E pedal.

0:8:55 "JFK theme" in D-maj (horns) against low Db (low strings) and temporary $\mathrm{F} \sharp+\mathrm{D} \sharp$ pedal (high strings).

0:9:31 Horn plays motivic major second (A-G) from "Motorcade" over C pedal, segues into steady muffled drum music for next cue

Audio and video of Eisenhower "Military Industrial Complex" warning.

Voiceover recounting Kennedy's election, video of Kennedy, montage including footage of civil rights movement, "Ich bin ein Berliner," etc.

Voiceover and historical footage recounting of secret CIA war against Cuba, Bay of Pigs incident.

Voiceover account of Cuban missile crisis.

Kennedy interview footage claiming war in Southeast Asia needs to be won by Vietnamese themselves; speech invoking genuine "Pax Americana," montage of Kennedy family.

Invented footage of Rose Cheramie warning of assassination plan, plus newsreel footage of Kennedy's arrival in Dallas.

Footage of beginning of Dallas motorcade.

Rapidly cut montage of newsreel and invented footage of parade surrounding motorcade, some suspicious occurrences within gathered crowds.

Slowed down footage of Kennedy's last moments.

Overlapping news broadcasts of assassination.

Garrison receives news of assassination, travels to New Orleans bar.

Walter Cronkite's broadcast in New Orleans bar, announcement of JFK's death.

Combination of horrified and elated reactions in bar.

Reactions in different New Orleans bar. 
"interlocking rhythmic disciplines" to use Williams's own phrase ${ }^{83}$ The sequence that results is indeed highly disciplined, every filmic component engineered to argue almost irresistibly for Garrison's multiple-gunman theory-down to the repetition of the Zapruder footage and Costner's litanization of the phrase "back-and-to-theleft."

The remorselessly manipulative scene is the summit of what Stephen Lavington calls Stone's "sledgehammer aesthetic." ${ }^{4}$ Through its bludgeoning together of music, imagery, and dialogue, the motorcade sequence cannily blends conventions of horror film scoring with processional music, producing something part parade, part funeral cortege, and part simple aural assault. Kennedy's theme is defiled and then buried, figuratively and literally, under layers of musical pandemonium, denied full expression by musical ideas associated with conflicting ideologies and lifestyles. And yet it is ironically in this purposefully obscured state that Williams's theme is at its most mythically honest. The meaning of the "Theme from JFK" depends on the impossibility of unambiguous concrete representation through musical devices. No matter how evocative the style topics, no matter how stirring the Americana codes, at best music can only imaginatively reconstruct, not resurrect, a lost public figure. The theme's significatory power is thus at its highest when filmic context draws attention to its own absence, fragility, or ephemerality. John Hellmann states, "The popular hero known as John F. Kennedy was a product, an image designed to both express and elicit desire. This object was constructed through a series of hero tales that, told and retold, produced a politician as the hero of an unfolding mythology. ... This modern American hero tale, the life and career of John F. Kennedy, is perhaps even the major American mythology of our time." ${ }^{85}$ Williams's attested aim to "portray something of the young President's character" notwithstanding, the thirty-fifth president, as rendered by Williams and Stone, amounts to a public recollection rather than an actual human being with interiority. This JFK is an image- romanticized, selective, and tragic — the mythical fallen King, always already lost.

\section{Reprobation and Rehabilitation in Nixon}

The balance of grim reality and hopeful idealization is reversed in Stone's Nixon. During its even longer running time (221 minutes), the film achieves a feeling of buzzing overrepresentation for the title character, who hardly ever leaves the screen. Nixon's score is far longer, more sustained in its musical arguments, and subject to more insightful motivic development. In tandem with Hopkins's raw performance, music helps lay bare the thirty-seventh president's personal demons and traumatic past. Yet the surfeit of characterization alludes to a lack deliberately structured into the very fabric of the film - a musical "hole" comparable to the one in $J F K$, but approached from the other direction, as surplus presence rather than absence. Overflow of personality contributes to the story's tragic dimensions, the

\footnotetext{
${ }^{83}$ Dyer, "'Hook' and 'JFK", A5.

${ }^{84}$ Stephen Lavington, Oliver Stone (London: Virgin Books, 2004), 132.

${ }^{85}$ Hellmann, Kennedy Obsession, ix-x.
} 


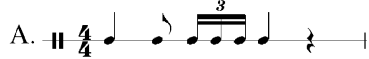
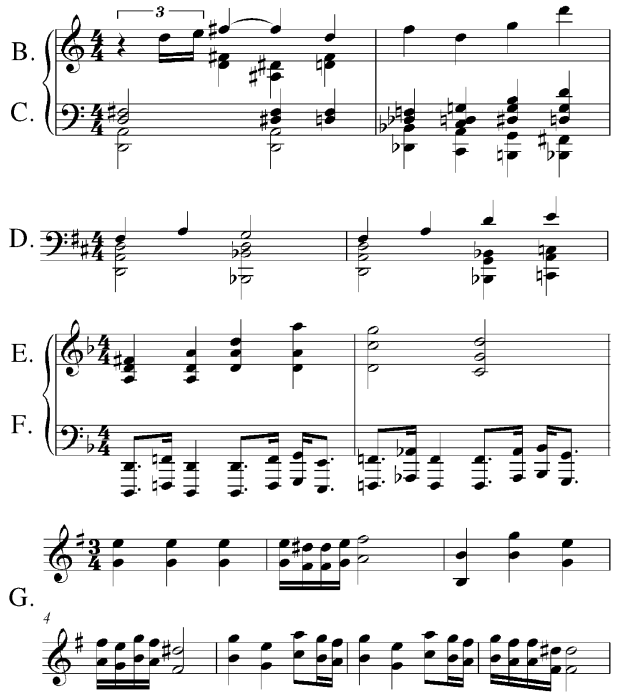
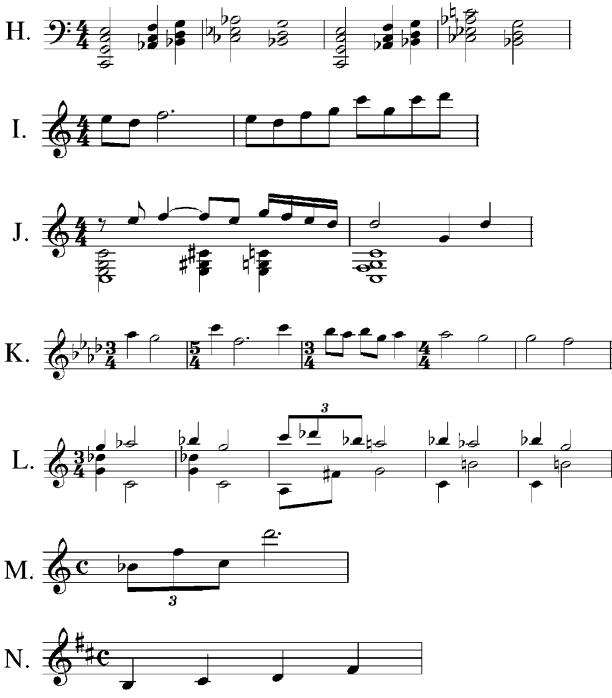

O.

Example 4. Themes and motifs in Nixon (1995, Cinergi Pictures Entertainment, Inc.), directed by Oliver Stone and produced by Dan Halsted, Eric Hamburg, Richard Rutowski, Oliver Stone, Clayton Townsend, and Andrew G. Vajna. Musical score by John Williams. Transcriptions by author.

sense that the character is too big for the stage he is placed on. At the same time, it helps manufacture a broader narrative about the nature of historical representation. As Gavin Smith argues, "Ultimately Stone is giving us not just an imploded, psychodramatized Nixon but also a represented and displaced Nixon, endlessly fabricated and disassembled by history-making cameras and microphones in the era of mass media and of his own paranoia. His images and speech are insatiably captured, framed, fragmented, and reconstituted into a delirium of visual styles and formal devices.... [Stone's film] is a historical drama about the constructing and recording of history." 86 Williams's musical characterization of Nixon is in line with this combination of psychodramatic excess and refractive deconstruction. A glimpse at the inventory of recurrent musical materials of the score (Example 4) reveals a strikingly different pattern than for JFK. The president of this film garners no one single motto, but a spiraling collection of motifs and submotifs; his thematic identity is located at once everywhere and nowhere in the score.

Much material originates from the thematic fount of the film's trailer, which includes a specially composed overture that Williams later titled "1960s: The Turbulent Years" for the soundtrack album. With a large-scale ternary structure, "The Turbulent Years" inverts the film's tripartite narrative structure. The film's dramatic arc details Nixon's struggles and failures in Acts I and III, and his rise to power in Act II. ${ }^{87}$ By contrast, the overture sandwiches its most tumultuous music between

${ }^{86}$ Smith, "Dark Side," 6-9. Robert Kolker makes a similar point about representation as applied to $J F K$, describing it as a "formal investigation of the ways images are manufactured to produce memory and history." Robert Kolker, A Cinema of Loneliness (New York: Oxford University Press, 2011), 70.

${ }^{87}$ See Charles Deemer, "Nixon: A Symphonic Tragedy," in Creative Screenwriting 3, no. 2 (Fall 1996): 31-46. 
bookends of ambivalent aspiration. From "The Turbulent Years," one may discern the gestation of the aforementioned "napalm recollections" (Example 4A), along with a half dozen other motifs that range from cataclysmic (Example $4 \mathrm{~F}$ and $\mathrm{G}$ ) to growling but noble (Example 4B, C, E) to almost bucolic (Example 4D and J). In the film these particles attach to and develop alongside various details of Nixon's career. Motif G, used sparingly but usually in an aggressive guise, is clearly coded as "villainous" and resembles Williams's themes for antagonists in the Star Wars series. Those motifs associated with "striving" (Example 4B, D, E, and H) are subjected to particularly elaborate development, their exaggerated rise/fall contours often set against ungainly chromatic harmonies. Yet, as with the "Prologue" from JFK, these musical ideas are not simply "themes for Nixon." The fact that the source of the motifs refers to time period rather than the man himself illustrates the extent to which history, rather than just personality, is at stake in Williams's score.

The composer's role in constructing history is at its most active in his scoring of Nixon's speeches. ${ }^{88}$ Especially acute in these scenes is the clash of Williams's penchant for monumentalization with Stone's kinetic and fragmentary aesthetic. Musical accompaniment varies from wounded (the 1962 "Last" Press Conference, 0:37:00) to "Beastly" (the 1973 Watergate address 2:43:20 and the "I am not a crook" address, 3:06:40) to blandly patriotic (the "Checkers" speech, 0:41:46). The rendering of Nixon's farewell address upon his resignation (3:22:23, immediately following the "deathbed realization" scene) is illustrative of these competing aesthetics. The speech plays over the end credits, placed there because of its superfluity to the film's core drama, with the narrative proper having reached its logical conclusion with Nixon's moment of cathartic self-realization and subsequent abdication. ${ }^{89}$ Treating the speech as excess allows a problematic aspect of the scene to be sidestepped. The recreation of the farewell address appears not only to let Nixon off the hook, but gives him a warm and dignified glow after hours of portraying him as a hopelessly compromised antihero. Stone himself admits many critics read the scene as "hagiography," while he himself thought of it as generally "neutral," and at most "ironic." 90

Williams is complicit in this side-stepping strategy. Elements in the music suggest that the final cue operates as an extra-narratival bookend, thus garnering a formal "escape clause" from its responsibility to color the main, more tragic action. In line with his usual approach, the composer grants the end-credits sequence a sustained reworking of his themes, fuller and longer breathed than

\footnotetext{
${ }^{88}$ Nixon's speeches are scored in a way that invites comparison with the less ambiguous mode of oratorical accompaniment. Where music for speeches in Stone's films tends to increase ambivalence, William's scoring for Spielberg-directed scenes typically removes ambiguity. Buhler critiques the rhetorical impact of music in a key scene in Amistad in "Analysing Interactions of Music and Film," in Film Music: Critical Approaches, ed. Kevin J. Donnelly (New York: Continuum International Publishing Group, 2001), 49-50.

${ }^{89}$ Stone, Nixon DVD commentary (3:21:00).

${ }^{90}$ Stone, Nixon DVD commentary (3:22:00). Many critics argued that Stone went too softly on Nixon in this film, a fault the director himself came to acknowledge. James Hoberman said of this pair of films: "If JFK was scurrilous hero worship, Nixon is uplifting whitewash." Hoberman, "Bugging Out," Village Voice, 26 December 1995, 53. See also Maureen Dowd, "Liberties; Nix 'Nixon'—Tricky Pix," in New York Times, 21 December 1995, A29.
} 
heard previously. In the farewell address, Williams strings together several motifs (Example 4B, C, D, E, and M) into a bittersweet valediction redolent of the more dignified Coplandiana from JFK, leaning on the pastoralist codes he elsewhere dutifully eschews. ${ }^{91}$ Despite the summational quality, however, the sequence still functions as underscore for dialogue. And as such, it is not a neutral witness but an active participant in producing the tone of the cinematically restaged historical event. Significantly, the motifs do not entirely shed their gnarled qualities. In fact, being clothed in sentimental harmonies and dignified orchestration only seems to highlight the motif's gnarled, melodically awkward, and diatonically inassimilable qualities. The disconnect between outward appearance and intrinsic brokenness subtly works against a too-straightforwardly sympathetic identification with Nixon. Stone himself subverts the implicitly critical tone of Williams's music when he substitutes the belligerent concluding pages of the underscore cue with a military band performance of "The Star Spangled Banner" and a choral rendition of the folksong "Shenandoah." Rehabilitation of a sort certainly does take place on the soundtrack, but as incorporated into the musical texture, Williams's chosen motifs resist ennobling thematic transformation. His music is not "neutral," as Stone naively views the whole scene, but nor is it uncomplicatedly on the side of Nixon's oratory.

The varied and sometimes contradictory approaches to historical representation in Nixon lead to a constant tug between identification and distanciation, between viewing events unfold at a critical remove and being immersed within the tumult of history as if it were directly taking place. The dichotomy of political representation is at play most urgently with the structural centerpiece of the film and score: the 1968 Republican National Convention (1:18:37-1:24:06). Nixon's acceptance address in the film is a composite of several speeches with some invented and adapted components. ${ }^{92}$ An already-collage-like oration overlays a complex montage of Hopkins speaking, historical and staged footage of the "silent majority," and widespread civil unrest. Table 2 provides a formal analysis of the speech, aligning the various stages of Nixon's oratory with each of the musical cue's thirteen sections. Also indicated are the montage images that sometimes align, but more frequently clash in tone with Nixon's exhortations: the audio-visual disjunctions are either direct (as when Hopkins promises "full prosperity in peacetime" while brutal police suppression is shown) or ironic (as when the image of Martin Luther King is seen while the duplicitous candidate extols the "truth").

The swing of Stone's editorial sledgehammer is answered with forcefully foregrounded scoring. Music amplifies the rhetorical punch of every line Hopkins delivers, and through its symphonic bombast it suggests that the convention was

${ }^{91}$ The farewell scene and Williams's music for it were cleverly spoofed in an episode of Seinfeld, "The Cadillac Part 2" (Episode 7x15, writ. Larry David and Jerry Seinfeld, dir. Andy Ackerman. Castle Rock Entertainment, 1996).

${ }^{92}$ See Nixon's 1968 nomination speech (available at http://www.presidency.ucsb.edu/ ws/?pid=25968) and 1969 "Vietnamization" speech (available at http://www.presidency.ucsb.edu/ ws/?pid=2303). Some lines were also inspired by Nixon's “Toward Freedom From Fear" essay in Richard M. Nixon, Nixon Speaks Out (New York: Nixon-Agnew Campaign Committee, 1968), $135-52$. 
Table 2. Musical structure of Nixon, "Miami Convention, 1968."

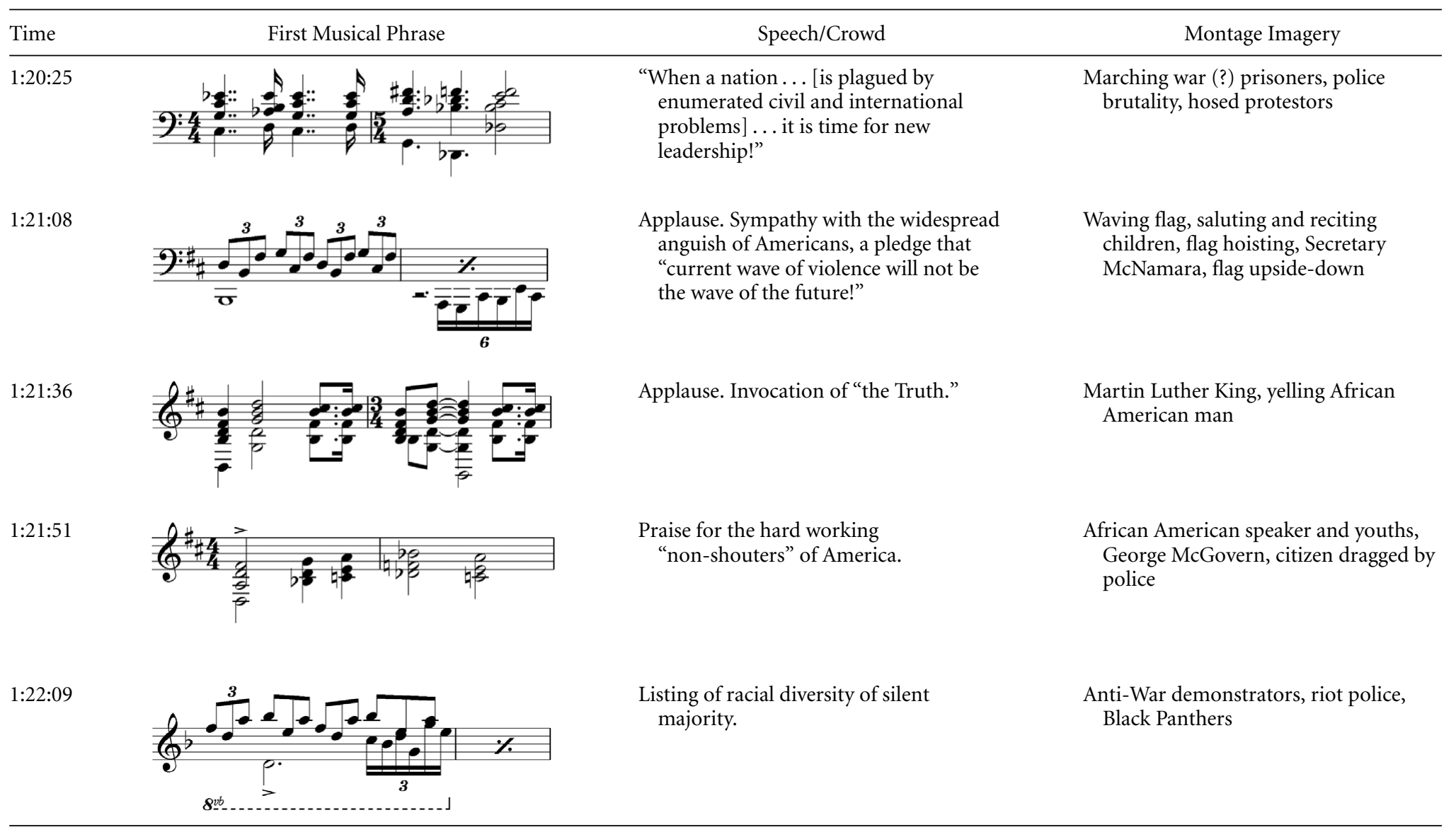
(

"current wave of violence will not be children, flag hoisting, Secretary American man
Amelling African George McGovern, citizen dragged by police

nti-War demonstrators, riot police, Black Panthers 
Table 2. Continued.

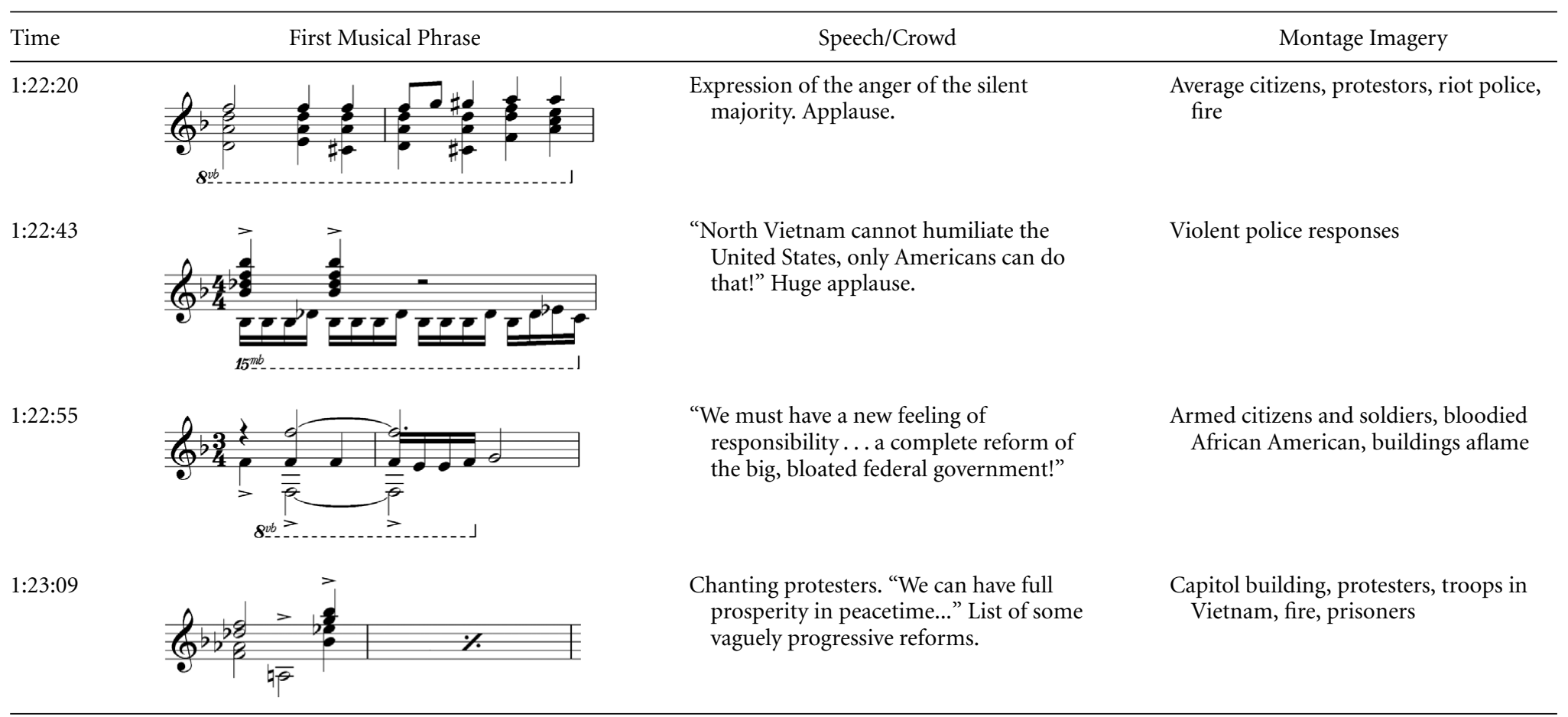


Table 2. Continued.

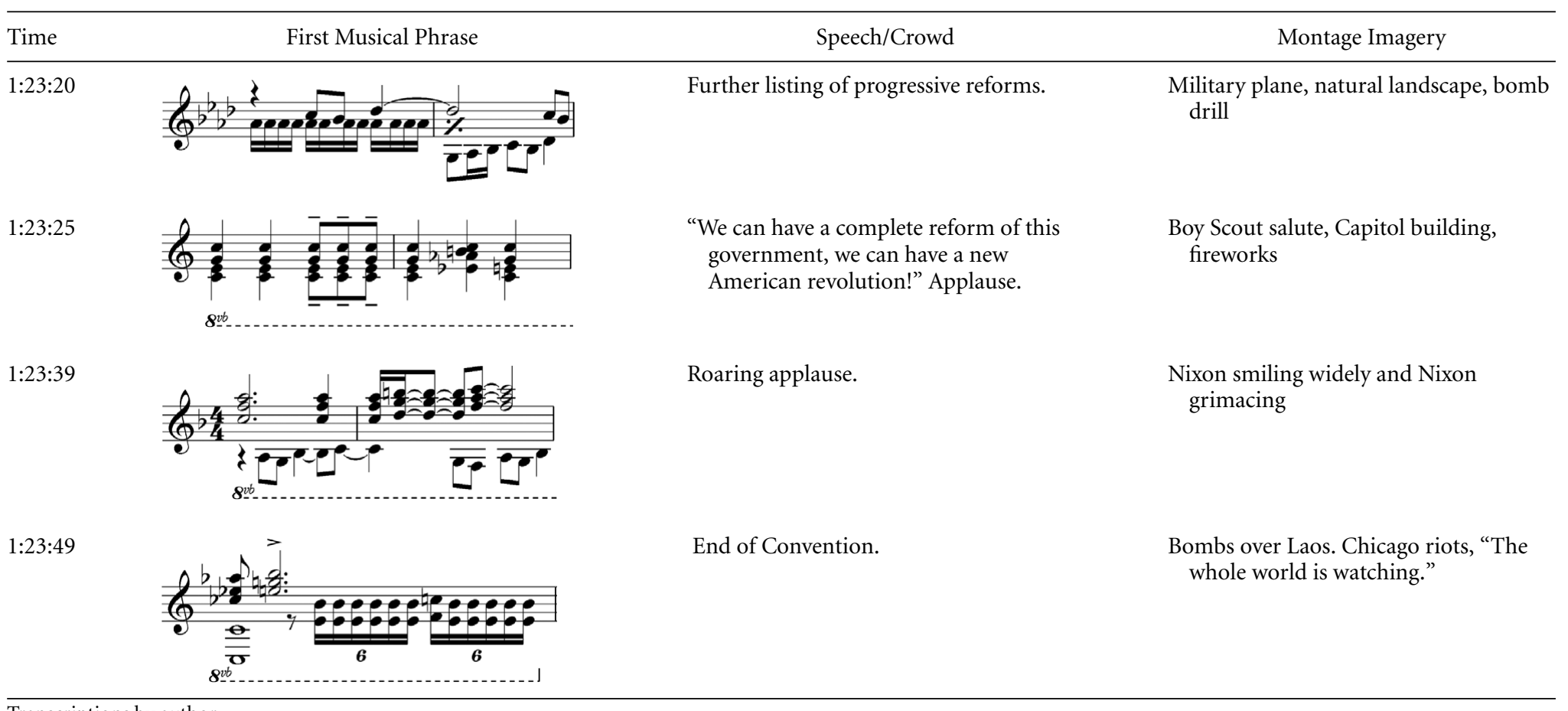




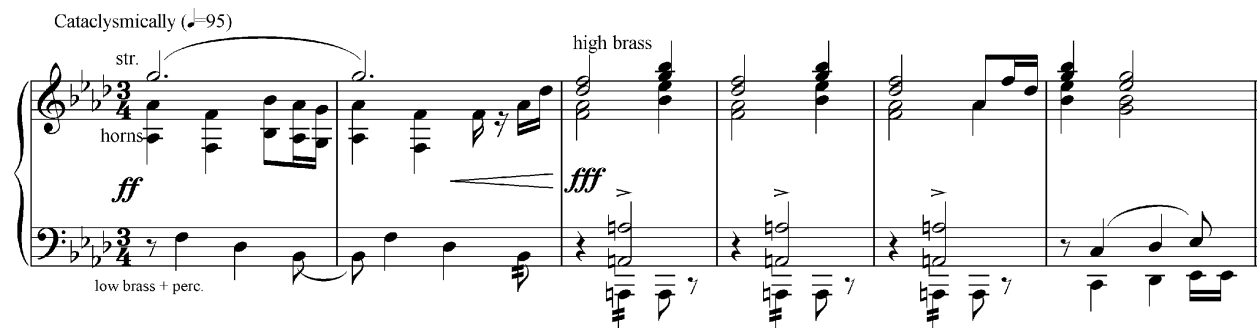

Example 5. Climax of "Miami Convention, 1968." From Nixon (1995, Cinergi Pictures Entertainment, Inc.), directed by Oliver Stone and produced by Dan Halsted, Eric Hamburg, Richard Rutowski, Oliver Stone, Clayton Townsend, and Andrew G. Vajna. Musical score by John Williams. Transcription by author.

not only a turning point in Nixon's career, but in the history of the United States as well. Nevertheless, despite its manipulative aggression, the music once again pushes a scene into surprisingly ambivalent territory. The cue "Miami Convention, 1968” alternates statements of various motifs against a cyclone of briefly visited keys, twelve large-scale modulations in all. Craning higher in an ever-intensifying series of climaxes, the piece builds to a delirious, dissonant climax after Hopkins bellows, "We must have a complete reform of the big, bloated federal government!" as massive waves of $\mathrm{D} b$ major crash against the rocks of an A $\downarrow$ pedal (Example 5).

In conjunction with the rapid succession of incendiary images, Williams throttles the listener with roiling ostinatos and sinister fanfares. While closely synchronized at the speech's beginning such that applause lines signal new formal sections, the music becomes progressively less tethered to the beats of Hopkins's speech. This decoupling enables moments of striking counterpoint. Such is the case when Nixon calls for "new responsibility" while images flash of urban carnage and a positively Darth Vader-esque statement of motif G snarls. Proper realignment occurs at the conclusion of the address with a series of discordant hexatonic juxtapositions ( $C$ against $\mathrm{E}$ - and $\mathrm{A} b$-minor). It is a fittingly grotesque harmonic gambit for a transition in which fireworks and cheering give way to bombs over Laos and angry chants from the Chicago riots.

There is something more than a little dangerous in the way that Williams uses music to monumentalize Nixon's acceptance address. The score seems to support two equivocal, mutually exclusive interpretations, one critical, the other sympathetic. According to the first hearing, every negatively valenced musical topic underlines the divisiveness and hypocrisy of the orator and his "Southern strategy" of garnering support by playing on a feeling of reactionary alienation. The brass perorations that are so prominent in the cue-martial, inflated, never quite shorn of the element of disruptive dissonance-rightly belong to a tyrant re-ascendant. ${ }^{93}$ "Miami Convention, 1968" on this hearing is music for a pseudo-fascist spectacle.

${ }^{93}$ It is surely no accident that Nixon's lengthiest theme (motif G) shares melodic and harmonic characteristics with "The Imperial March" (a.k.a. "Darth Vader's Theme”) from the Star Wars series. Notable too is the dark chorale that initiates the cue, which was reworked for Star Wars: Episode III to accompany Emperor Palpatine's declaration of the galactic empire and assumption of the role of totalitarian dictator. 
The second, more dangerous hearing is for filmgoers to be swept along, moved by the ferocity of Hopkins's delivery, perhaps enticed by the progressive tone of his later promises. Rather than construe the minor-mode fanfares as aspersions on Nixon's character, one might hear those musical elements as characterizations of his foes, the very "shouters" of social unrest that his "great silent majority" struggles to be heard over. On this reading, Williams's music is akin to a heroic tone poem, and Nixon its implied protagonist, complete with the victorious tolling of $\mathrm{C}$ major when he closes by promising a "New American Revolution!" With the churning orchestra supporting his rhetoric, Nixon battles away the forces of disorder and unrest, meaning what he says, and earning his thematic apotheosis, Black Panthers and Chicago rioters be damned.

Choosing between readings would seem to oblige us to impose a certain ideological lens on both the composer and the filmgoer. Is Williams so reactionary a composer that he would allow such a lionization of a disgraced president? Are we so easily enamored with representations of power that we instinctively hear negative musical topics as belonging to a narratively declared enemy, rather than a historically disastrous presidency? Or, alternatively, is Williams so repulsed by Nixon that he offers him the same musical treatment he would for a Dark Lord of the Sith in some fictional Manichean universe? And are we suitably prejudiced to read it in those terms as well? As usual, the hermeneutics of such contrapuntalor-parallel (or critical-or-sympathetic) are grossly facile and reductive. The fact that the scene leaves these starkly opposed interpretations open speaks to a deeper, more productive ambivalence contained in the film's soundtrack. The actual effect of music in Nixon's acceptance speech is purposely bivalent and discomfiting, both condemnation of "The Beast" and an invitation to participate in a bit of musical authoritarianism, if just for three minutes.

\section{Music as History}

In his essay "Oliver Stone as Historian,” Robert Rosenstone claims that the director's filmography is "history" in a strong, albeit postmodern, sense: history as argument, metaphor, and symbol imposed upon traces of the past. ${ }^{94}$ In Stone's hands, cinema, the "most literal of media never delivers a literal representation of the past. It speaks about the past, it comments on it, it raises the issues of the past and tells us what those issues (can) mean. But it cannot show the past to us." 95 Oliver Stone's movies, Rosenstone argues, strive to make meaning of the past, selectively envisioning significant episodes, contesting conventional and institutional narratives, and revising those narratives to instruct and rouse audiences. The movies "engage the discourse of history and add something to that discourse."

Whether one agrees with Rosenstone that Stone's paranoid and outraged films constitute history in the same way the work of academic historians does, it is apparent that John Williams's music is bound up with the same postmodern sort of

\footnotetext{
${ }^{94}$ Rosenstone, "Stone as Historian," in Oliver Stone's USA: Film, History, and Controversy, ed. Robert Brent Toplin (Lawrence: University Press of Kansas, 2000), 26-39.

${ }^{95}$ Rosenstone, "Stone as Historian," 34.
} 
authorship of historical meaning. As I have demonstrated, Williams's scores for JFK and Nixon assume much of the responsibility for creating of Stone's cinematically constructed metanarratives. The character traits Williams chooses to highlight through musical codes; the manner in which his themes symbolize ideas and eras rather than personages; the way music solidifies film-spanning metanarratives about power-these acts of compositional interpretation are part of a historical discourse as potent as any screenplay. Williams's music goes beyond neutral underscoring, and, indeed, beyond ideologically colored musings on history, whether nostalgic or condemnatory (or both). The scores are, in Rosenstone's sense, acts of writing history in their own right. Williams's presidential portraits do not pretend to "show the past to us." But at every juncture they tell us what the issues of the past (can) mean.

\section{References}

\section{Books, Articles, and Scores}

Ansari, Emily Abrams. "Aaron Copland and the Politics of Cultural Diplomacy." Journal of the Society for American Music 5 no. 3 (2001): 335-364.

Ansen, David. "What Does Oliver Stone Owe History?" Newsweek, December 23 $1991,49$.

Anson, Robert Sean. “The Shooting of JFK." Esquire, November 1991, 93-102, 174-176.

Audissino, Emilio. John William's Film Music: Jaws, Star Wars, Raiders of the Lost Ark, and the Return of the Classical Hollywood Music Style. Madison: University of Wisconsin Press, 2014.

Baker, Adam. "Cries and Whispers." Sight and Sound 1 no. 10 (February 1992): 25. Bashwiner, David. "Musical Analysis for Multimedia: A Perspective from Music Theory." In The Psychology of Music in Multimedia, ed. Siu-Lin Tan et al., 89117. Oxford: Oxford University Press, 2013.

Beaver, Frank. Oliver Stone: Wakeup Cinema. New York: Macmillan, 1994.

—. "Citizen Nixon': Oliver Stone's Wellesian View of a Failed Public Figure." In The Films of Oliver Stone, ed. Don Kuntz, 275-84. Lanham, MD: Scarecrow Press, 1997.

Bergman Crist, Elizabeth. Music for the Common Man: Aaron Copland during the Depression and War. Oxford: Oxford University Press, 2005.

Bick, Sally M. A. "Composers on the Cultural Front: Aaron Copland and Hanns Eisler in Hollywood." Ph.D. dissertation, Yale University, 2001.

Buhler, James. "Star Wars, Music, and Myth." In Music and Cinema, ed. James Buhler, Caryl Flinn, and David Neumeyer, 33-57. Hanover, NH: Wesleyan University Press, 2000.

- "Analysing Interactions of Music and Film." In Film Music: Critical Approaches, ed. Kevin J. Donnelly, 39-61. New York: Continuum International Publishing Group, 2001.

Burlingame, John. "Williams' Music for Obama's Ears.” Variety, 15 January 2009, http://variety.com/2009/music/news/williams-music-to-obama-sears-1117998645/. 
Cieutat, Michel and Ciment, Michel. "Interview with Oliver Stone: America, Land of Failure.” In Oliver Stone Interviews, ed. Charles L. P. Silet, 172-82. Jackson: University Press of Mississippi, 2001.

Cook, David. Lost Illusions: American Cinema in the Shadow of Watergate. Berkeley: University of California Press, 2000.

Cooke, Mervyn. A History of Film Music. Oxford: Oxford University Press, 2008.

Deemer, Charles. "Nixon: A Symphonic Tragedy." Creative Screenwriting 3 no. 2, Fall 1996: 31-46.

Dowd, Maureen. “Liberties; Nix 'Nixon'—Tricky Pix.” New York Times, 21 December 1995, 29.

Dyer, Richard. "You'll Be Hearing From Him.” Boston Globe, 31 August 1989, 77.

_. "'Hook' and 'JFK' Are Latest Hits with the John Williams Touch." Boston Globe, 19 January 1992, A5.

Ehrenstein, David. "JFK-A New Low for Hollywood." The Advocate, 14 January 1992, 78-81.

Feeney, Mark. Nixon at the Movies: A Book About Belief. Chicago: University of Chicago Press, 2004.

Frick, Daniel. Reinventing Richard Nixon: A Cultural History of an American Obsession. Lawrence: University of Kansas Press, 2008.

Gianos, Philip L. Politics and Politicians in American Film. Westport, CT: Praeger, 1998.

Hamburg, Eric, ed. Nixon: An Oliver Stone Film. New York: Hyperion, 1995.

Hanley, Jason. "Natural Born Killers: Music and Image in Postmodern Film." In Postmodern Music/Postmodern Thought, ed. Joseph Auner and Judith Lockhead, 335-60. New York: Routledge, 2002.

Hellmann, John. The Kennedy Obsession: The American Myth of JFK. New York: Columbia University Press, 1997.

Hoberman, James. “Bugging Out.” Village Voice, 26 December 1995, 53.

Hofstadter, Richard. “The Paranoid Style in American Politics.” Harpers, November 1964, 77-86.

Howard, Luke. “The Popular Reception of Samuel Barber's "Adagio for Strings." American Music 25 no. 1 (2007): 50-80.

Johnson, Timothy. John Adams's Nixon in China: Musical Analysis, Historical and Political Perspectives. Burlington, VT: Ashgate, 2011.

Kagan, Jeremy, ed. Directors Close Up: Interviews with Directors Nominated for Best Film by the Director's Guild of America. Lanham, MD: Scarecrow Press, 2006.

Kagan, Norman. The Cinema of Oliver Stone. New York: Continuum, 2000.

Kolker, Robert. A Cinema of Loneliness. New York: Oxford University Press, 2011.

Larson, Thomas. The Saddest Music Ever Written: The Story of Samuel Barber's Adagio for Strings. New York: Pegasus Books, 2012.

Lavington, Stephen. Oliver Stone. London: Virgin Books, 2004.

Lehman, Frank. "Hollywood Cadences: Music and the Structure of Cinematic Expectation." Music Theory Online 19, no. 4 (2013): http://www.mtosmt.org/ issues/mto.13.19.4/mto.13.19.4.lehman.html. 
Lerner, Neil. “Copland's Music of Wide Open Spaces: Surveying the Pastoral Trope in Hollywood.” Musical Quarterly 85, no. 3 (2001): 477-515.

- "Nostalgia, Masculinist Discourse and Authoritarianism." In Off The Planet: Music, Sound, and Science Fiction Cinema, ed. Philip Hayward, 96-109. Bloomington: Indiana University Press, 2004.

Mackey-Kallis, Susan. Oliver Stone's America: "Dreaming the Myth Outward.” Boulder, CO: Westview Press, 1996.

Mailer, Norman. "Footfalls in the Crypt." Vanity Fair, February 1992, 124-29, 171.

Marshall, Kingsley. "Stone's Improbable W." In Presidents in the Movies: American History and Politics on Screen, ed. Iwan W. Morgan, 177-192. New York: Palgrave Macmillan, 2011.

Mendelsohn, Daniel. “J.F.K., Tragedy, Myth.” The New Yorker, 22 November 2013. http://www.newyorker.com/online/blogs/books/2013/11/jfk-tragedy-myth. html.

Merluzeau, Yann. “An Interview with John Williams.” Soundtrack! 12, no. 41 (September 1993): 4-9.

Morgan, Iwan W. “The President Impeached: Tennessee Johnson and Nixon.” In Presidents in the Movies: American History and Politics on Screen, ed. Iwan W. Morgan, 151-76. New York: Palgrave MacMillan, 2011.

Moynihan, Daniel Patrick. "The Paranoid Style." Washington Post, 29 December 1991, C1.

Nein, John. "The Republic of Sorkin: A View from the Cheap Seats.” In Considering Aaron Sorkin: Essays on the Politics, Poetics, and Sleight of Hand in the Films and Television Series, ed. Thomas Fahey, 193-210. Jefferson, NC: McFarland, 2005.

"Newsmeat: Federal Campaign Contributions Since 1978, John Williams." http://web.archive.org/web/20130117210739/http://newsmeat.com/celebrity political_donations/John_T_Williams.

Nixon, Richard M. Nixon Speaks Out: Major Speeches and Statements by Richard M. Nixon in the Presidential Campaign of 1968. New York: Nixon-Agnew Campaign Committee, 1968.

Riordan, James. Stone: The Controversies, Excesses, and Exploits of a Radical Filmmaker. New York: Hyperion, 1995.

Robertson, Malcolm D. “Roy Harris's Symphonies: An Introduction.” Tempo 207 (December 1998): 9-14.

Rosar, William. "The Dies Irae in Citizen Kane: Musical Hermeneutics Applied to Film Music.” In Film Music: Critical Approaches, ed. Kevin J. Donnell. New York: Continuum, 2001.

Rosenstone, Robert. "Stone as Historian." In Oliver Stone's USA: Film, History, and Controversy, ed. Robert Brent Toplin, 26-39. Lawrence: University Press of Kansas, 2000.

Schoening, Benjamin, and Eric Kasper. Don't Stop Thinking about the Music: The Politics of Songs and Musicians in Presidential Campaigns. Lanham, MD: Lexington Books, 2012.

Seelye, Katharine Q. "Seeking the Proper Tone for Obama's Inauguration." New York Times, 9 December 2008. http://www.nytimes.com/2008/ 12/09/world/americas/09iht-09inaug.18506795.html?pagewanted=all. 
Silet, Charles L. P. ed. Oliver Stone Interviews. Jackson: University Press of Mississippi, 2001.

Smith, Gavin. “The Dark Side." Sight and Sound 6, no. 3 (March 1996): 6-9.

Stone, Oliver and Zachary Sklar. JFK: The Book of the Film. New York: Applause Books, 1992.

Stone, Oliver. "Oliver Stone Talks Back.” Premiere, January 1992, 67-72. . "On Nixon and JFK." In Oliver Stone's USA: Film, History, and Controversy, ed. Robert Brent Toplin, 249-98. Lawrence: University Press of Kansas, 2000.

. "Stone on Stone's Image." In Oliver Stone's USA: Film, History, and Controversy, ed. Robert Brent Toplin, 40-65. Lawrence: University Press of Kansas, 2000.

Sturken, Marita. "Reenactment, Fantasy, and the Paranoia of History: Oliver Stone's Docudramas." History and Theory 36 no. 4 (1997): 64-79.

Thurmaier, David. "Ives and Lincoln, The Great Commoners?: Understanding 'Uncommon' Aspects of an Ives Song." Paper given at the Annual Conference of the Society for American Music, Lancaster, PA, March 6-9, 2014.

Welsh, James M. and Donald M. Whaley, eds. The Oliver Stone Encyclopedia. Lanham, MD: Scarecrow Press, 2013.

Whaley, Donald. “'Biological Business-As-Usual:' The Beast in Oliver Stone's Nixon." In Hollywood's White House: The American Presidency in Film and History, ed. Peter C. Rollins and John E. O’Connor, 275-87. Lexington: University Press of Kentucky, 2003.

Wicker, Tom. One of Us: Richard Nixon and the American Dream. New York: Random House, 1991.

Williams, John. Suite from J.F.K. Milwaukee, WI: Hal Leonard, 1992.

Witcher, Russ. After Watergate: Nixon and the Newsweeklies. Lanham, MD: University Press of America, 2000.

Yarborough, Jeff. "Heart of Stone: Writer-Director Oliver Stone Opens Up on Sex, JFK, and Harvey Milk." The Advocate, 7 April 1992, 44-49.

\section{Discography and Filmography}

Ackerman, Andy, dir. Seinfeld: “The Cadillac Part 2.” Writ. Larry David and Jerry Seinfeld. West Hollywood, CA: Castle Rock Entertainment, 1996.

Lewis, Brent. Earth Tribe Rhythms. Los Angeles: Ikauma Records, COM-3300, 1991, CD.

Lucas, George. Star Wars Episode III: Revenge of the Sith. Los Angeles: 20th Century Fox, 2005, DVD.

Reiner, Robert, dir. The American President. 1995; Universal City, CA: Universal Pictures, 1999, DVD.

Stone, Oliver, dir. Born on the Fourth of July. 1989; Universal City, CA: Universal Pictures, 2000, DVD.

- JFK: The Director's Cut. 1991; Burbank, CA: Warner Bros. Home Video, 2011, DVD.

- Nixon: Election Year Edition. 1995; Burbank, CA: Buena Vista Home Entertainment, 2008, DVD. 
W. 2008; Santa Monica, CA: Lions Gate, 2009, DVD.

Williams, John. American Journey. New York: Sony Classical, SK 89364, 2002, CD.

- Born on the Fourth of July. Universal City, CA: MCA Records, 2292 57071-2, 1989, CD.

- JFK: Original Motion Picture Soundtrack. New York: Elektra Entertainment, 7559-61293-1, 1992, CD.

- Lincoln. New York: Sony Classical, 88725446852, 2012, CD.

- Nixon: Original Motion Picture Soundtrack. Burbank, CA: Hollywood Records, 162 043-2, 1995, CD. 